\title{
Polypyridyl-functionalizated alkynyl gold(।) metallaligands supported by tri- and tetradentate phosphanes $\uparrow$
}

Cite this: Dalton Trans., 2017, 46 13920

Received 26th July 2017,

Accepted 12th September 2017

DOI: $10.1039 / \mathrm{c} 7 \mathrm{dt0} 02732 \mathrm{j}$

rsc.li/dalton

\author{
Montserrat Ferrer, (D) *a Leticia Giménez, ${ }^{a}$ Albert Gutiérrez, ${ }^{a}$ João Carlos Lima, (D) b \\ Manuel Martínez, (D) a Laura Rodríguez, (DD a,c Avelino Martín, (DD ${ }^{d}$ Rakesh Puttreddy \\ and Kari Rissanen (D)
}

A series of alkynyl gold $(1)$ tri and tetratopic metallaligands of the type $\left[A u_{3}(C \equiv C-R)_{3}\left(\mu_{3}\right.\right.$-triphosphane $\left.)\right]$ ( $\mathrm{R}=$ 2,2'-bipyridin-5-yl or $\mathrm{C}_{10} \mathrm{H}_{7} \mathrm{~N}_{2}$, 2,2':6',2'-terpyridin-4-yl or $\mathrm{C}_{15} \mathrm{H}_{10} \mathrm{~N}_{3}$; triphosphane = 1,1,1-tris(diphenylphosphanyl)ethane or triphos, 1,3,5-tris(diphenylphosphanyl)benzene or triphosph) and $\left[\mathrm{Au}_{4}(\mathrm{C} \equiv \mathrm{C}-\mathrm{R})_{4}\right.$ ( $\mu_{4}$-tetraphosphane)] $\left(\mathrm{R}=\mathrm{C}_{10} \mathrm{H}_{7} \mathrm{~N}_{2}, \mathrm{C}_{15} \mathrm{H}_{10} \mathrm{~N}_{3}\right.$; tetraphosphane = tetrakis(diphenylphosphanylmethyl)methane or tetraphos, 1,2,3,5-tetrakis(diphenylphosphanyl)benzene or tpbz, tetrakis(diphenylphosphaneylmethyl)-1,2ethylenediamine or dppeda) were obtained in moderate to good yields. All complexes could be prepared by a reaction between the alkynyl gold(I) polymeric species $[\mathrm{Au}(\mathrm{C} \equiv \mathrm{C}-\mathrm{R})]_{n}$ and the appropriate polyphosphane. An alternative strategy that required the previous synthesis of the appropriate acetylacetonate precursors $\left[A u_{n}(\operatorname{acac})_{n}\left(\mu_{n}\right.\right.$-polyphosphane)] ("acac method") was assayed, nevertheless only the polyacac derivatives $\left[\mathrm{Au}_{3}(\mathrm{acac})_{3}\left(\mu_{3}\right.\right.$-triphosphane)] (triphosphane $=$ triphos and triphosph) and $\left[\mathrm{Au}_{4}(\mathrm{acac})_{4}\left(\mu_{4}\right.\right.$-tetraphos)] could be isolated and characterized. All compounds were characterized by IR, multinuclear NMR spectroscopy and ESI (+) mass spectrometry. The $\mathrm{X}$-ray crystal structure of complexes $\left[\mathrm{Au}_{4}\left(\mathrm{C} \equiv \mathrm{C}-\mathrm{C}_{10} \mathrm{H}_{7} \mathrm{~N}_{2}\right)_{4}\left(\mu_{4}\right.\right.$-tetraphos $\left.)\right]$ and $\left[\mathrm{Au}_{4}\left(\mathrm{C} \equiv \mathrm{C}-\mathrm{C}_{10} \mathrm{H}_{7} \mathrm{~N}_{2}\right)_{4}\left(\mu_{4}\right.\right.$-tpbz)] showed the involvement of all the gold atoms in close intramolecular $\mathrm{Au} \cdots \mathrm{Au}$ contact as well as intermolecular $\pi$ stacking interactions between the aromatic rings of the polypyridyl ligands. The photophysical properties of the synthesized compounds were carefully studied and used as a probe of their possible use as multidentate ligands for $\mathrm{Cu}(\mathrm{I})$ and $\mathrm{Zn}\left({ }_{\mathrm{I}}\right)$. The UV-Vis speciation studies of the complexation reactions were conducted via metal titration and, in most cases the dangling units of the ligand were found to behave in a fairy independent manner. While in the case of $\mathrm{Cu}(1)$ multiple equilibria exist in solution a single complex is detected for $\mathrm{Zn}(॥)$ under the conditions studied.

\section{Introduction}

Gold(I) molecular materials have become an evolving field of research in the last few decades due to their promising appli-

\footnotetext{
${ }^{a}$ Departament de Quimica Inorgànica i Orgànica, Secció de Química Inorgànica. Universitat de Barcelona, c/Martí i Franquès 1-11, 08028 Barcelona, Spain. E-mail: montse.ferrer@qi.ub.es

${ }^{b}$ LAQV-REQUIMTE, Departamento de Quimica, Universidade Nova de Lisboa, Monte de Caparica, Portugal

${ }^{c}$ Institut de Nanociència $i$ Nanotecnologia (IN $\left.{ }^{2} U B\right)$. Universitat de Barcelona, 08028 Barcelona, Spain

${ }^{d}$ Departamento de Química Inorgánica, Campus Universitario-Edificio de Farmacia, Universidad de Alcalá, 28871 Alcalá de Henares, Spain

${ }^{e}$ Department of Chemistry, University of Jyväskylä, POB 35, 40014 Jyväskylä, Finland $\dagger$ Electronic supplementary information (ESI) available: ${ }^{1} \mathrm{H},{ }^{31} \mathrm{P}$ and ${ }^{13} \mathrm{C}$ NMR spectra of the compounds, UV-VIS and emission spectra, crystallographic data and stability constants. CCDC 1559283 (6) and 1561541 (7). For ESI and crystallographic data in CIF or other electronic format see DOI: 10.1039/c7dt02732j
}

cations in fields such as sensing, ${ }^{1-3}$ non-linear optics, ${ }^{4-6}$ catalysis, $^{7-10}$ therapeutics $^{11-13}$ and bioimaging. ${ }^{11,12,14}$ This interest in gold(I) complexes mainly arises from their rich luminescence properties ${ }^{1,15-19}$ as well as their predisposition to establish aurophilic interactions. ${ }^{20-24}$

In particular, gold(I) alkynyl systems ${ }^{25,26}$ are especially attractive due to the preference for linear two-coordinate geometry of gold(I), together with the linearity of the alkynyl unit and its $\pi$-unsaturated nature. These privileged features have made alkynyl gold(I) complexes ideal candidates as building blocks to assemble a great variety of organometallic supramolecular structures that frequently present aurophilic interactions and significant luminescence properties. ${ }^{22,27-37}$

In addition to the possibility of establishing aurophilic interactions, the functionalization of the alkynyl moiety with $\mathrm{N}$-donor groups in gold(I) alkynyl compounds provides an alternative and/or complementary approach to obtain heterometallic and/or multicomponent complexes with a wide range 
of geometries. With this in mind, we synthesized a series of phosphane gold(I) ethynylpyridine complexes that, in spite of bearing terminal $\mathrm{N}$-donor pyridine groups, ${ }^{38,39}$ did not allow us to build heterometallic assemblies. All the attempts to use the named pyridine derivatives in self-assembly reactions resulted in either complex mixtures in solution or very insoluble materials that could not be characterized.

After the failure of the pyridine appended gold(I) species to act as metallaligands, and as a rational extension of our studies, we directed our attention to the use of polypyridylfunctionalized alkynyl ligands such as 5-ethynyl-2,2'-bipyridine and $4^{\prime}$-ethynyl-2,2':6',2'-terpyridine to obtain our targeted gold(I) donor compounds. These polydentate N-donors should facilitate and stabilize the coordination of a wide range of d- and f-block metallic units through polypyridyl chelation to the prefabricated gold(I) alkynyl compounds. ${ }^{40}$ Moreover, the possibility of the incorporation of photo- and/or redox-active metal fragments in combination with the known luminescence properties of alkynyl gold(I) compounds could give rise to interesting properties suitable for potential applications.

In fact, some research groups have recently described the synthesis of alkynyl gold(I) complexes with terminal $2,2^{\prime}$-bipyridine ${ }^{41-46}$ or $2,2^{\prime}: 6^{\prime}, 2^{\prime \prime}$-terpyridine units. ${ }^{41,47-50}$ Interestingly, however, in spite of the stability of these metallaligands, a limited number of reports on the supramolecular coordination chemistry of these species can be found in the literature. Some years ago, Chen and co-workers described the isolation of tetrametallic $\mathrm{Au}_{2} \mathrm{Ln}_{2}$ ( $\mathrm{Ln}=$ lanthanide) arrays formed by the establishment of aurophilic interactions. ${ }^{42}$ Very recently, Vicente and co-workers reported the obtention of appealing supramolecular architectures like triple-stranded helicates, ${ }^{51,52}$ helical dimers ${ }^{53}$ rigid-rod complexes and coordination oligomers. ${ }^{54}$

Noteworthily, all the reported alkynyl gold(I) compounds with pendant polypyridyl moieties mentioned above are supported by mono or diphosphanes as auxiliary ligands, and consequently are able to act as mono or ditopic metallaligands. However, neither tri nor tetratopic analogous systems have been described so far. Indeed, although phosphanes and diphosphanes have been widely used as ligands in the chemistry of alkynyl gold(I) compounds, ${ }^{25}$ the number of derivatives based on tri or tetradentate phosphanes is rather limited, ${ }^{36,39,55-59}$ despite their potential in the construction of multimetallic assemblies. The use of tri or tetratopic building blocks should increase the complexity of the obtained heterometallic frameworks, allowing the obtention of architectures with a great diversity of nuclearities and/or topologies and unique properties. ${ }^{60}$

Given these considerations, we describe herein the preparation and characterization of a series of different tri and tetraphosphane alkynyl gold(I) derivatives with appended bipyridine or terpyridine moieties, suitable for participating in coordination reactions. The photophysical properties of the synthesised compounds together with a preliminary spectrophotometric study of how these properties are modified when they coordinate to $\mathrm{d}^{10}$ ions like $\mathrm{Cu}(\mathrm{I})$ and $\mathrm{Zn}(\mathrm{II})$ are also reported.

\section{Results and discussion}

\section{Synthesis of poly(diphenylphosphanyl)benzene ligands}

The tri- and tetraphosphanes with a benzene core used in this work (i.e. triphosph and tpbz) are interesting and versatile ligands in coordination chemistry due to the possibility of obtaining polynuclear derivatives. However, they have been barely explored most probably owing to their laborious and no reproducible synthesis. Since their preparation from $\mathrm{PPh}_{3}$ and $\mathrm{Na}$ metal in dry liquid ammonia described by McFarlane and co-workers, ${ }^{101}$ only one report dealing with an improved obtention of tpbz (from $\mathrm{PPh}_{2} \mathrm{Cl}$ and $\mathrm{Na}$ metal in THF as starting materials) can be found in the literature. ${ }^{61}$ However, the latter method is time consuming and the reported yield is only moderate. In this work we have significantly improved the synthesis of both poly(diphenylphosphanyl)benzene ligands by refluxing commercially available potassium diphenylphosphide in THF and appropriate fluoroarene for 4 hours (Scheme 1). This method was assayed after the work of James and co-workers, ${ }^{62}$ who described it for other polyphosphanes and resulted in a significant improvement of the reproducibility and the yield of the desired compounds.

\section{Synthesis of alkynyl gold(I) complexes}

Except for the case of tpbz and dppeda derivatives, two methods were used to prepare the targeted polynuclear alkynyl gold(I) compounds (Schemes 2 and 3). Although the general method used to synthesize related compounds involves a direct reaction between the polymer $[\mathrm{Au}(\mathrm{C} \equiv \mathrm{C}-\mathrm{R})]_{n}$ and the free phosphanes (polymer method), ${ }^{41,42,50,55}$ the laborious syntheses of 5-ethynyl-2,2'-bipyridine, and 4'-ethynyl-2,2':6',2"terpyridine and the moderate yields of these reactions prompted us to assay an alternative strategy based on the reaction of acetylacetonato phosphane complexes with the terminal alkynes ("acac method"). ${ }^{63,64}$ In fact, the acac derivatives $\left[\mathrm{Au}_{3}(\mathrm{acac})_{3}\left(\mu_{3}\right.\right.$-tripod $\left.)\right]$ and $\left[\mathrm{Au}_{3}(\mathrm{acac})_{3}\left(\mu_{3}\right.\right.$-triphos $\left.)\right]$ proved to be useful as intermediates in the obtention of supramolecular metallocryptands. ${ }^{65}$

Polymer method. Compounds $\left[\mathrm{Au}_{3}\left(\mathrm{C} \equiv \mathrm{C}-\mathrm{C}_{10} \mathrm{H}_{7} \mathrm{~N}_{2}\right)_{3}\left(\mu_{3}\right.\right.$-triphosphane)] (triphosphane $=$ triphos (4) and triphosph (5)) and $\left[\mathrm{Au}_{4}\left(\mathrm{C} \equiv \mathrm{C}-\mathrm{C}_{10} \mathrm{H}_{7} \mathrm{~N}_{2}\right)_{4}\left(\mu_{4}\right.\right.$-tetraphosphane) $]$ (tetraphosphane = tetraphos (6), tpbz (7) and dppeda (8)) were obtained in moderate to good yields by reacting $\left[\mathrm{Au}\left(\mathrm{C} \equiv \mathrm{C}-\mathrm{C}_{10} \mathrm{H}_{7} \mathrm{~N}_{2}\right)\right]_{n}$ with the appropriate tri- or tetraphosphane in a $3: 1$ and $4: 1$ molar ratio, respectively. Analogously, $\left[\mathrm{Au}_{3}\left(\mathrm{C} \equiv \mathrm{C}-\mathrm{C}_{15} \mathrm{H}_{10} \mathrm{~N}_{3}\right)_{3}\left(\mu_{3}\right.\right.$-triphosphane $\left.)\right]$

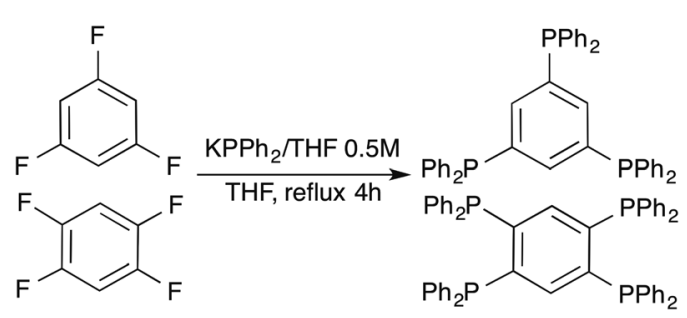

Scheme 1 Synthesis of poly(diphenylphosphanyl)benzene ligands. 


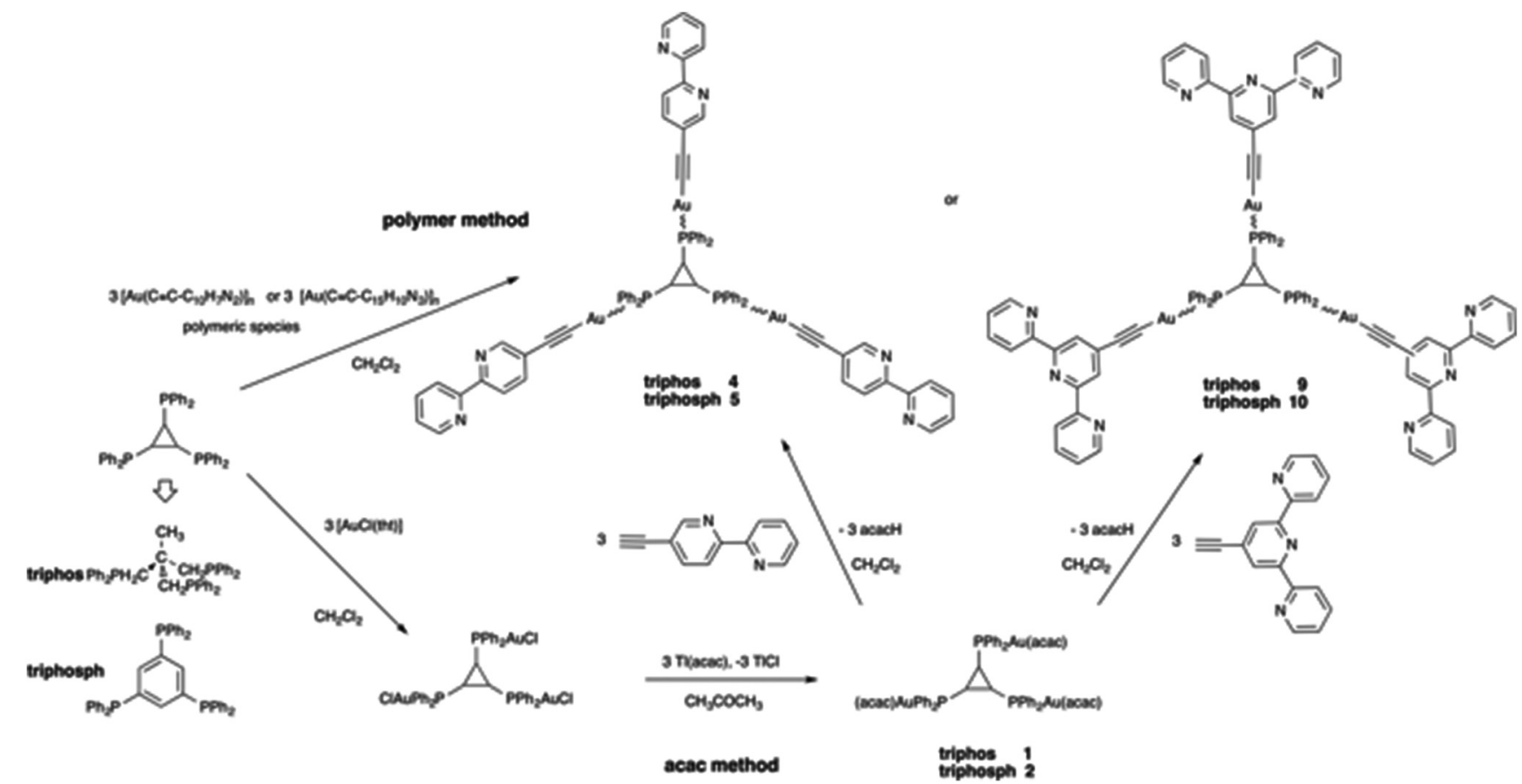

Scheme 2 Synthesis of tritopic gold(I) metallaligands.

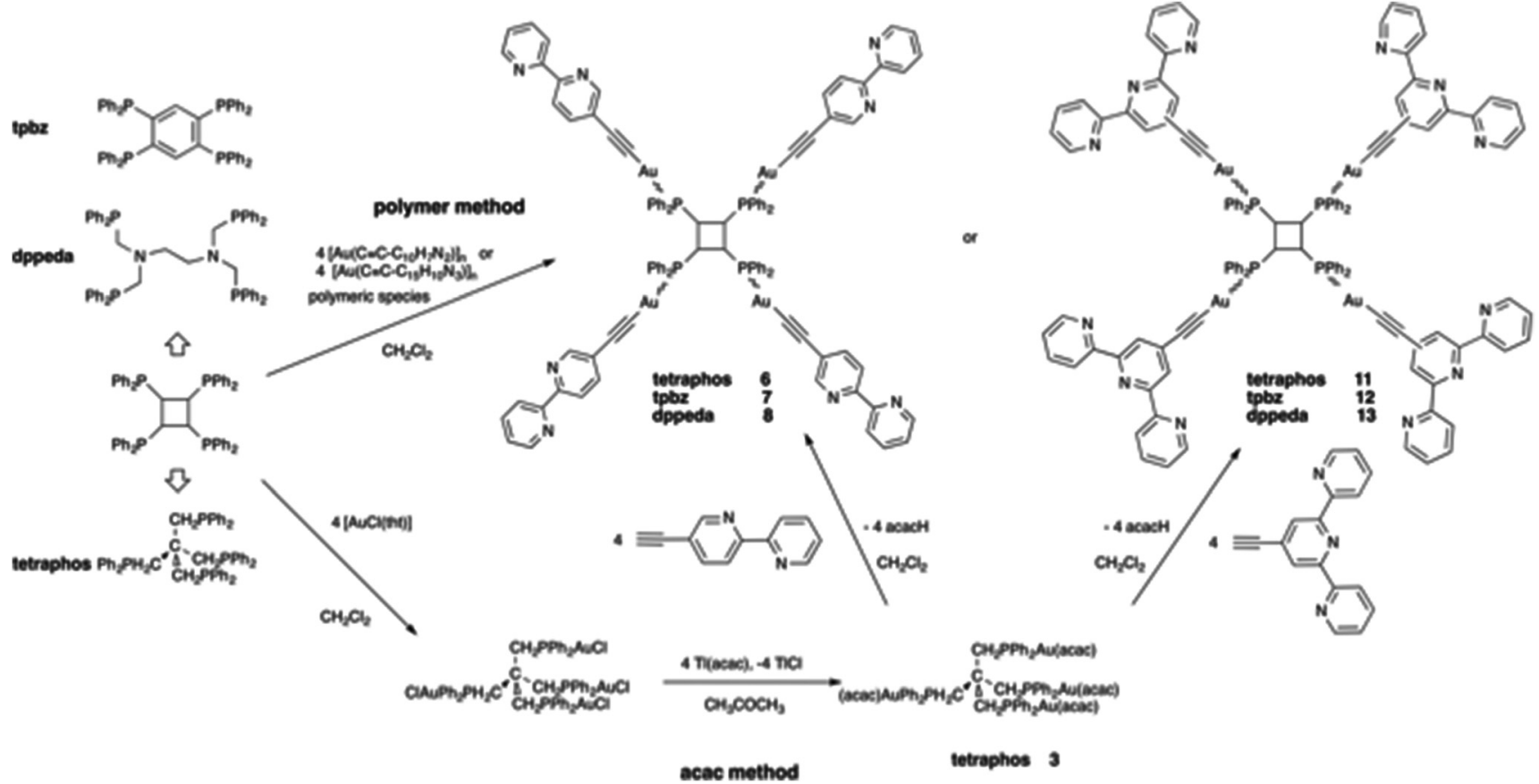

Scheme 3 Synthesis of tetratopic gold(I) metallaligands.

(triphosphane $=$ triphos (9) and triphosph (10)) and $\left[\mathrm{Au}_{4}\left(\mathrm{C} \equiv \mathrm{C}-\mathrm{C}_{15} \mathrm{H}_{10} \mathrm{~N}_{3}\right)_{4}\left(\mu_{4}\right.\right.$-tetraphosphane) $]$ (tetraphos (11), tpbz (12) and dppeda (13)) were obtained by reacting $\left[\mathrm{Au}\left(\mathrm{C} \equiv \mathrm{C}-\mathrm{C}_{15} \mathrm{H}_{10} \mathrm{~N}_{3}\right)\right]_{n}$ and the appropriate polyphosphane.

acac method. The acac derivatives $\left[\mathrm{Au}_{3}(\mathrm{acac})_{3}\left(\mu_{3}\right.\right.$-triphosphane)] (triphosphane $=$ triphos (1) and triphosph (2)) and
$\left[\mathrm{Au}_{4}(\mathrm{acac})_{4}\left(\mu_{4}\right.\right.$-tetraphos $\left.)\right]$ (3) were obtained by reacting a $10 \%$ excess of the required quantity of $\mathrm{Tl}(\mathrm{acac})$ with the appropriate chloro(polyphosphane)gold(I) compound in acetone solution in the dark. The progress of the reaction was monitored by ${ }^{31} \mathrm{P}$ NMR spectroscopy and complete consumption of the starting gold(I) compound was observed after $48 \mathrm{~h}$ for $\mathbf{1}$, one week 
for 2 and $72 \mathrm{~h}$ for 3 . At this point, the ${ }^{31} \mathrm{P}$ NMR spectra showed one singlet downfield shifted $c a .20 \mathrm{ppm}$ with respect to the corresponding chloro precursors, accordingly with the complete substitution of the chloro by the acetylacetonate ligands. In the case of compounds $\left[\mathrm{Au}_{3}(\mathrm{acac})_{3}\left(\mu_{3}\right.\right.$-triphosphane)] (triphosphane $=$ triphos (1) and triphosph (2)), the ${ }^{1} \mathrm{H}$ NMR spectra display a doublet at ca. $2.5 \mathrm{ppm}$ with ${ }^{3} J(\mathrm{P}-\mathrm{H}) \approx 11 \mathrm{~Hz}$ assigned to the $\mathrm{CH}$ of the acac ligand. This fact together with the presence in the IR spectra of two strong broad vibrations below $1600 \mathrm{~cm}^{-1}$ is consistent with a $\kappa \mathrm{C}^{2}$ coordination mode for this ligand, typically found in gold(I) derivatives. ${ }^{66-68}$ After their isolation in the solid state and their characterization by elemental analyses, and IR and NMR spectroscopy, compounds 1-3 were reacted with the terminal alkynes 5-ethynyl2,2'-bipyridine and 4'-ethynyl-2,2':6',2'-terpyridine in a suitable molar ratio and the expected gold(I) derivatives $\left[\mathrm{Au}_{3}(\mathrm{C} \equiv \mathrm{C}-\right.$ $\mathrm{R})_{3}\left(\mu_{3}\right.$-triphosphane)] (triphosphane $=\operatorname{triphos}(\mathbf{4}$ and $\mathbf{9})$ and triphosph (5 and 10)) and $\left[\mathrm{Au}_{4}(\mathrm{C} \equiv \mathrm{C}-\mathrm{R})_{4}\left(\mu_{4}\right.\right.$-tetraphos)] (6 and 11) were obtained in moderate yield after long reaction times (from $4 \mathrm{~h}$ for 4 to 3 days for 11). As a general trend, longer reaction times and lower yields are observed by increasing the number of phosphorus centres (tri to tetraphosphanes) and the bulkiness of the polypyridyl ligand (bipyridyl to terpyridyl). The tpbz compound could not be synthesized by this method due to the impossibility of preparation of the corresponding tetrachloro species. In the case of dppeda, the reaction between $\mathrm{Tl}(\mathrm{acac})$ and the tetrachloro species did not allow the obtention of the desired acac derivative. A complex set of signals in the ${ }^{31} \mathrm{P}$ NMR spectra of the reaction solution was obtained instead of the expected singlet.

Obviously, in this case, the "acac method" did not bring improvement to the more general method based on the use of polymeric alkynyl gold(I) species although it allowed us to prepare a series of polynuclear acetylacetonato gold(I) derivatives that can have a widespread use as reactive species in organometallic synthesis.

\section{Characterization of alkynylgold(I) complexes}

Complexes 4-13 were characterized by elemental analyses, IR and $\left({ }^{1} \mathrm{H},{ }^{31} \mathrm{P}\right.$ and $\left.{ }^{13} \mathrm{C}\right)$ NMR spectroscopy and ESI $(+)$ mass spectrometry. Due to the chemical equivalence of the $\mathrm{P}$ atoms within each compound, ${ }^{31} \mathrm{P}\left\{{ }^{1} \mathrm{H}\right\}$ NMR spectra show one sharp singlet, which is shifted ca. 50 ppm downfield from that corresponding to the free polyphosphanes and slightly shifted upfield compared to that of the parent acac compounds.

${ }^{1} \mathrm{H}$ NMR and ${ }^{13} \mathrm{C}\left\{{ }^{1} \mathrm{H}\right\}$ NMR spectra are indicative of the high symmetry of the molecules in accord with a single bipyridyl or terpyridyl environment. A complete assignment of proton and carbon NMR signals of both phosphanes and polypyridyl alkynyl ligands can be found in the Experimental section. This assignment was fully supported by COSY, gHSQC and gHMBC 2D experiments (for NMR spectra see the ESI $\dagger$ ). Regarding the ${ }^{13} \mathrm{C}\left\{{ }^{1} \mathrm{H}\right\}$ NMR spectra, two doublets corresponding to the carbon atoms of the acetylene unit bonded to $\mathrm{Au}$ are observed at $c a .140\left(\mathrm{C}_{\alpha}\right)$ and $102\left(\mathrm{C}_{\beta}\right)$ with C-P coupling constants around 140 and $25 \mathrm{~Hz}$, respectively. In the particular case of tpbz derivatives (compounds 7 and 12) the resonances of the acetylenic carbons appear as multiplets or apparent triplets due to second order effects that can be attributed to a large ${ }^{31} \mathrm{P}-{ }^{31} \mathrm{P}$ coupling transmitted through the aromatic ring and/or the existence of intramolecular $\mathrm{Au} \cdots \mathrm{Au}$ interactions in solution. As it will be seen later on, this aurophilic interaction has been observed in the solid state for the bipy derivative (7). In addition to satisfactory NMR analysis the structure of the compounds in solution was supported by mass spectrometry. Generally, the MS ESI(+) spectra of the obtained compounds display an intense peak that corresponds to that of the double protonated $\left[\mathrm{M}+2 \mathrm{H}^{+}\right]^{2+}$ species together with the $[\mathrm{M}-\mathrm{C} \equiv \mathrm{C}-\mathrm{R}]^{+}$ signal that arises from the loss of either bipyridyl or terpyridyl fragments from the corresponding parent compound. Moreover, in certain cases, additional peaks resulting from polyprotonation are found. For instance, compound $\left[\mathrm{Au}_{4}\left(\mathrm{C} \equiv \mathrm{C}-\mathrm{C}_{15} \mathrm{H}_{10} \mathrm{~N}_{3}\right)_{4}\left(\mu_{4}\right.\right.$-tpbz) $]$ (12) shows signals due to mono- $\left[\mathrm{M}+\mathrm{H}^{+}\right]^{+}$, di- $\left[\mathrm{M}+2 \mathrm{H}^{+}\right]^{2+}$ tri- $\left[\mathrm{M}+3 \mathrm{H}^{+}\right]^{3+}$ and tetraprotonated $\left[\mathrm{M}+4 \mathrm{H}^{+}\right]^{4+}$ species.

\section{Crystallographic studies}

The crystal structures of $\left[\mathrm{Au}_{4}\left(\mathrm{C} \equiv \mathrm{C}-\mathrm{C}_{10} \mathrm{H}_{7} \mathrm{~N}_{2}\right)_{4}\left(\mu_{4}\right.\right.$-tetraphos $\left.)\right]$ (6) and $\left[\mathrm{Au}_{4}\left(\mathrm{C} \equiv \mathrm{C}-\mathrm{C}_{10} \mathrm{H}_{7} \mathrm{~N}_{2}\right)_{4}\left(\mu_{4}\right.\right.$-tpbz) $]$ (7) were determined by single-crystal X-ray diffraction. The molecular structure of compound 6 along with the selected bond distances and bond angles is shown in Fig. 1. The unit cell of the compound contains two different molecules where some differences can be found. Although both molecules display a conformation that favours the establishment of aurophilic interactions between pairs of branches, these are significantly stronger for the molecule on the right $(\mathrm{Au}(1 \mathrm{~A})-\mathrm{Au}(2 \mathrm{~A}) 2.9445(12)$ and $\mathrm{Au}(3 \mathrm{~A})-\mathrm{Au}(4 \mathrm{~A})$ $3.0356(10) \AA)$ than for the molecule on the left as shown in Fig. 1 (Au(1)-Au(2) 3.259(3) and $\mathrm{Au}(3)-\mathrm{Au}(4) 3.0310(11) \AA$ ). This conformation is similar to that found for the closely related compound $\left[\mathrm{Au}_{4}\left(\mathrm{C}_{6} \mathrm{~F}_{4} \mathrm{C}_{5} \mathrm{H}_{4} \mathrm{~N}\right)_{4}\left(\mu_{4}\right.\right.$-tetraphos $\left.)\right]$ where rather long (3.343(1) §) intramolecular $\mathrm{Au} \cdots \mathrm{Au}$ interactions were found between adjacent units. ${ }^{69}$ On the other hand, this disposition is in contrast with that described for the chloride derivative $\left[\mathrm{Au}_{4} \mathrm{Cl}_{4}\left(\mu_{4}\right.\right.$-tetraphos $\left.)\right]$, where a pair of gold centres lie far apart while the other two show a gold-gold contact of $3.34 \AA^{70}$ Interestingly, only three compounds bearing gold atoms in the four legs of tetraphos have been structurally characterized. An inspection of the structure packing reveals the formation of a supramolecular arrangement (Fig. S43 and S44 in the ESI $\dagger$ ) as a result of the establishment of intermolecular $\pi-\pi$ interactions between the bipyridine units attached to $\mathrm{Au}(2)-\mathrm{Au}(2), \mathrm{Au}(3)-$ $\mathrm{Au}(3 \mathrm{~A})$ or $\mathrm{Au}(4)-\mathrm{Au}(4 \mathrm{~A})$ pair of arms. The shortest $\pi-\pi$ contacts (intercentroid distance $=3.56 \AA$ ) are established between the bipyridyl rings of the $\mathrm{Au}(2)$ arms of neighbouring molecules. As a result of the presence of these intermolecular interactions, the $\mathrm{Au}(2)-\mathrm{C} \equiv \mathrm{C}-\mathrm{C}_{10} \mathrm{H}_{7} \mathrm{~N}_{2}$ moiety displays a particularly small value of the $\mathrm{C} \equiv \mathrm{C}-\mathrm{C}_{10} \mathrm{H}_{7} \mathrm{~N}_{2}$ angle $(\mathrm{C}(1 \mathrm{C})-\mathrm{C}(1 \mathrm{~B})-\mathrm{C}(16)$ $\left.165(6)^{\circ}\right)$ if it is compared with those found for the remaining analogous angles ( $\left.\mathrm{ca} .175^{\circ}\right)$. Interestingly, a search on CSD revealed that among the 157 hits containing $\mathrm{C} \equiv \mathrm{C}-\mathrm{C}_{10} \mathrm{H}_{7} \mathrm{~N}_{2}$ fragments only five display values lower than $166^{\circ}$ for the men- 


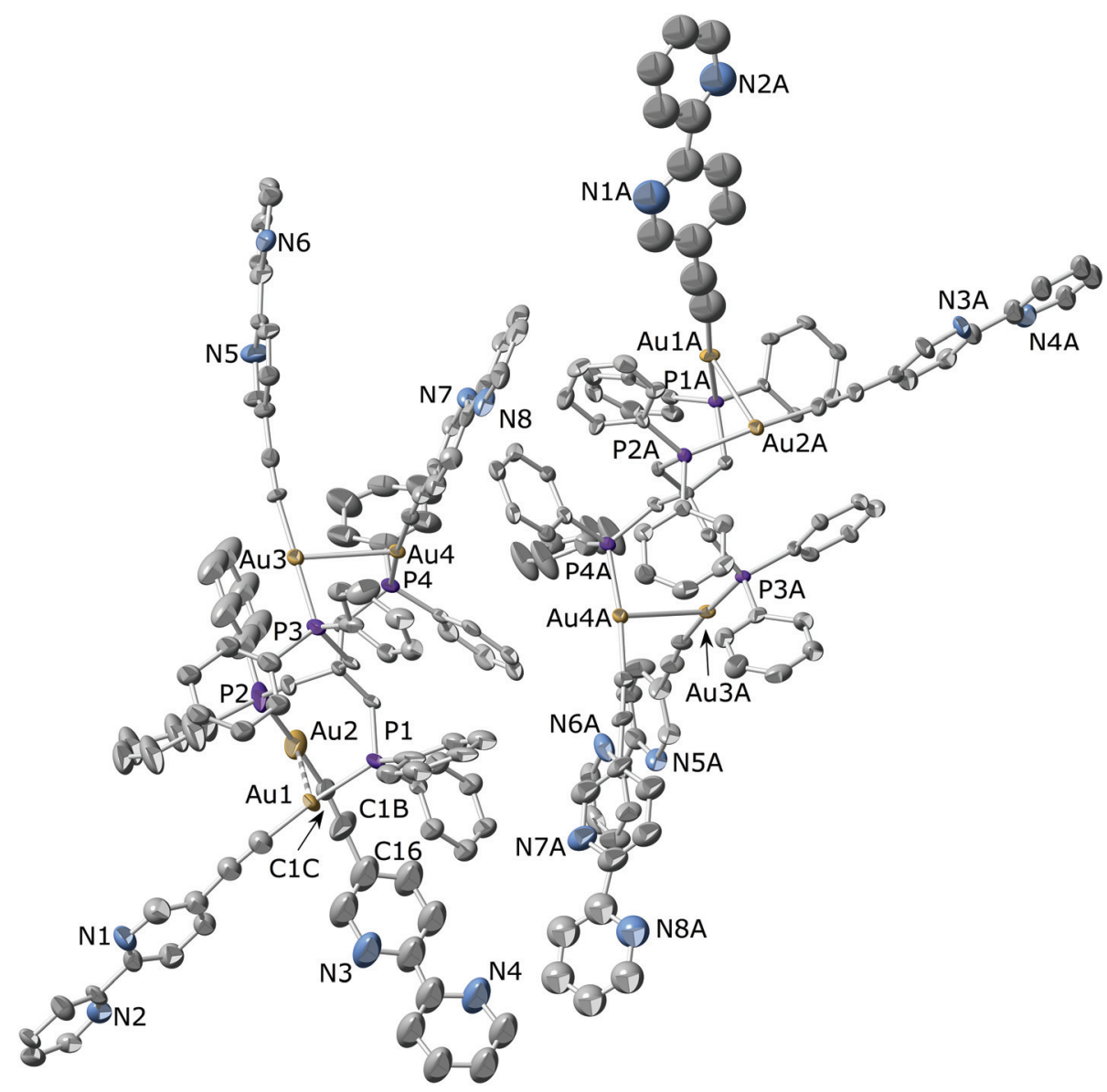

Fig. 1 Molecular structure of compound $\left[\mathrm{Au}_{4}\left(\mathrm{C} \equiv \mathrm{C}-\mathrm{C}_{10} \mathrm{H}_{7} \mathrm{~N}_{2}\right)_{4}\left(\mu_{4}\right.\right.$-tetraphos)] (6) showing the two different classes of molecules found in the crystal. Thermal ellipsoids are drawn at the $30 \%$ probability level. Hydrogen atoms have been omitted for clarity. Selected bond lengths ( $\AA$ ) and angles ('): $\mathrm{Au}(1)-\mathrm{Au}(2)$ 3.259(3), $\mathrm{Au}(3)-\mathrm{Au}(4)$ 3.0310(11), $\mathrm{Au}(1 \mathrm{~A})-\mathrm{Au}(2 \mathrm{~A})$ 2.9445(12), $\mathrm{Au}(3 \mathrm{~A})-\mathrm{Au}(4 \mathrm{~A}) 3.0356(10), \mathrm{Au}(1)-P(1) 2.260(5), A u(1)-C(1) 1.93(3)$, $\mathrm{Au}(2)-\mathrm{P}(2)$ 2.220(8), $\mathrm{Au}(2)-\mathrm{C}(1 \mathrm{C})$ 1.910(17), $\mathrm{Au}(3)-\mathrm{P}(3)$ 2.290(6), $\mathrm{Au}(3)-\mathrm{C}(25)$ 2.00(2), Au(4)-P(4) 2.273(4), $\mathrm{Au}(4)-\mathrm{C}(37) 2.045(18), \mathrm{Au}(1 \mathrm{~A})-\mathrm{P}(1 \mathrm{~A})$ 2.287(4), $A u(1 A)-C(1 A)$ 2.07(6), $A u(2 A)-P(2 A)$ 2.287(4), $A u(2 A)-C(13 A)$ 2.006(19), $A u(3 A)-P(3 A) 2.269(4), A u(3 A)-C(25 A) 2.01(2), A u(4 A)-P(4 A) 2.275(4)$, $\mathrm{Au}(4 \mathrm{~A})-\mathrm{C}(37 \mathrm{~A})$ 2.006(19); $\mathrm{P}(1)-\mathrm{Au}(1)-C(1)$ 172.9(10), $\mathrm{P}(2)-\mathrm{Au}(2)-C(1 \mathrm{C})$ 175.3(10), $\mathrm{P}(3)-\mathrm{Au}(3)-C(25)$ 177.0(8), $P(4)-A u(4)-C(37) \quad 173.0(5), P(1 A)-$ $A u(1 A)-C(1 A)$ 171.9(17), $P(2 A)-A u(2 A)-C(13 A)$ 171.7(6), $P(3 A)-A u(3 A)-C(25 A)$ 173.6(7), P(4A)-Au(4A)-C(37A) 173.6(6), Au(1)-C(1)-C(2) 170(3), Au(2)$C(1 C)-C(1 B)$ 162(4), $A u(3)-C(25)-C(26)$ 173(2), $A u(4)-C(37)-C(38) 172.2(19), A u(1 A)-C(1 A)-C(2 A)$ 167(7), $A u(2 A)-C(13 A)-C(14 A) 175(2), A u(3 A)-$ $C(25 A)-C(26 A)$ 171(2), $A u(4 A)-C(37 A)-C(38 A)$ 173(2), C(1)-Au(1)-Au(2) 94.5(10), C(25)-Au(3)-Au(4) 100.5(6), C(1A)-Au(1A)-Au(2A) 99.5(17), C(25A)$\mathrm{Au}(3 \mathrm{~A})-\mathrm{Au}(4 \mathrm{~A})$ 95.9(6), $P(2)-A u(2)-A u(1)$ 83.3(3), $P(4)-A u(4)-A u(3)$ 89.39(13), $P(2 A)-A u(2 A)-A u(1 A)$ 83.60(12), $P(4 A)-A u(4 A)-A u(3 A)$ 85.59(11), $C(1 C)-C(1 B)-C(16) 165(6)$.

tioned angle, ${ }^{52,71-74}$ in such a way that the formation of helicates ${ }^{52}$ cages $^{71}$ or stacking interactions ${ }^{74}$ is favoured.

The molecular structure of compound $\left[\mathrm{Au}_{4}(\mathrm{C} \equiv \mathrm{C}-\right.$ $\left.\mathrm{C}_{10} \mathrm{H}_{7} \mathrm{~N}_{2}\right)_{4}\left(\mu_{4}\right.$-tpbz)] (7) (Fig. 2) compares well with that of the closely related $\left[\mathrm{Au}_{4}\left(\mathrm{C} \equiv \mathrm{C}-\mathrm{C}_{6} \mathrm{H}_{5}\right)_{4}\left(\mu_{4}\right.\right.$-tpbz) $]$ described by Yam and co-workers. ${ }^{55}$ Analogously to the latter, the arrangement of every two adjacent $\mathrm{Au}-\mathrm{C} \equiv \mathrm{C}-\mathrm{C}_{10} \mathrm{H}_{7} \mathrm{~N}_{2}$ moieties displays a crossed geometry, although their relative disposition with respect to the central benzene core is not the same. In fact, an angle of $0^{\circ}$ is formed by the symmetry related $\mathrm{Au}(1)-\mathrm{Au}(2)$ and $\mathrm{Au}\left(1^{*}\right)-\mathrm{Au}\left(2^{*}\right)$ axes in the phenyl derivative while an almost perpendicular disposition $\left(71.4^{\circ}\right)$ is found between $\mathrm{Au}(1)-$ $\mathrm{Au}(1 \mathrm{~A})$ and $\mathrm{Au}(2)-\mathrm{Au}(2 \mathrm{~A})$ in compound 7. Besides, the distances between adjacent $\mathrm{Au}$ units in compound 7 ( $\mathrm{Au}(1)$ $\mathrm{Au}(1 \mathrm{~A}) 3.077(2)$ and $\mathrm{Au}(2)-\mathrm{Au}(2 \mathrm{~A}) 3.118(2) \AA)$ are shorter than in the phenyl derivative that displays a unique contact of 3.1541(4) A. A comparison between the structures of compounds 6 and 7 reveals a cisoid disposition of the $\mathrm{N}$ atoms within each bipyridyl unit in compound 7 (torsion angle between pyridine rings: $11.6^{\circ}$ and $28.8^{\circ}$ for $\mathrm{py}_{\mathrm{N} 1}-\mathrm{py}_{\mathrm{N} 2}$ and $\mathrm{py}_{\mathrm{N} 3}-\mathrm{py}_{\mathrm{N} 4}$, respectively) that contrasts with the transoid conformation determined for compound $\mathbf{6}$ (torsion angle between pyridine rings: $3.47^{\circ}-20.79^{\circ}$ ).

\section{Photophysical characterization}

Absorption and emission spectra of all the complexes were recorded in $10^{-6} \mathrm{M}$ dichloromethane solution at room temperature and the obtained data are summarized in Table 1.

All complexes display a vibronically resolved absorption profile centered at $c a .320 \mathrm{~nm}$ for bipy (4-8) and at ca. $290 \mathrm{~nm}$ for terpy (9-13) derivatives (Fig. S45 and S46 in the ESI $\dagger$ ) that 


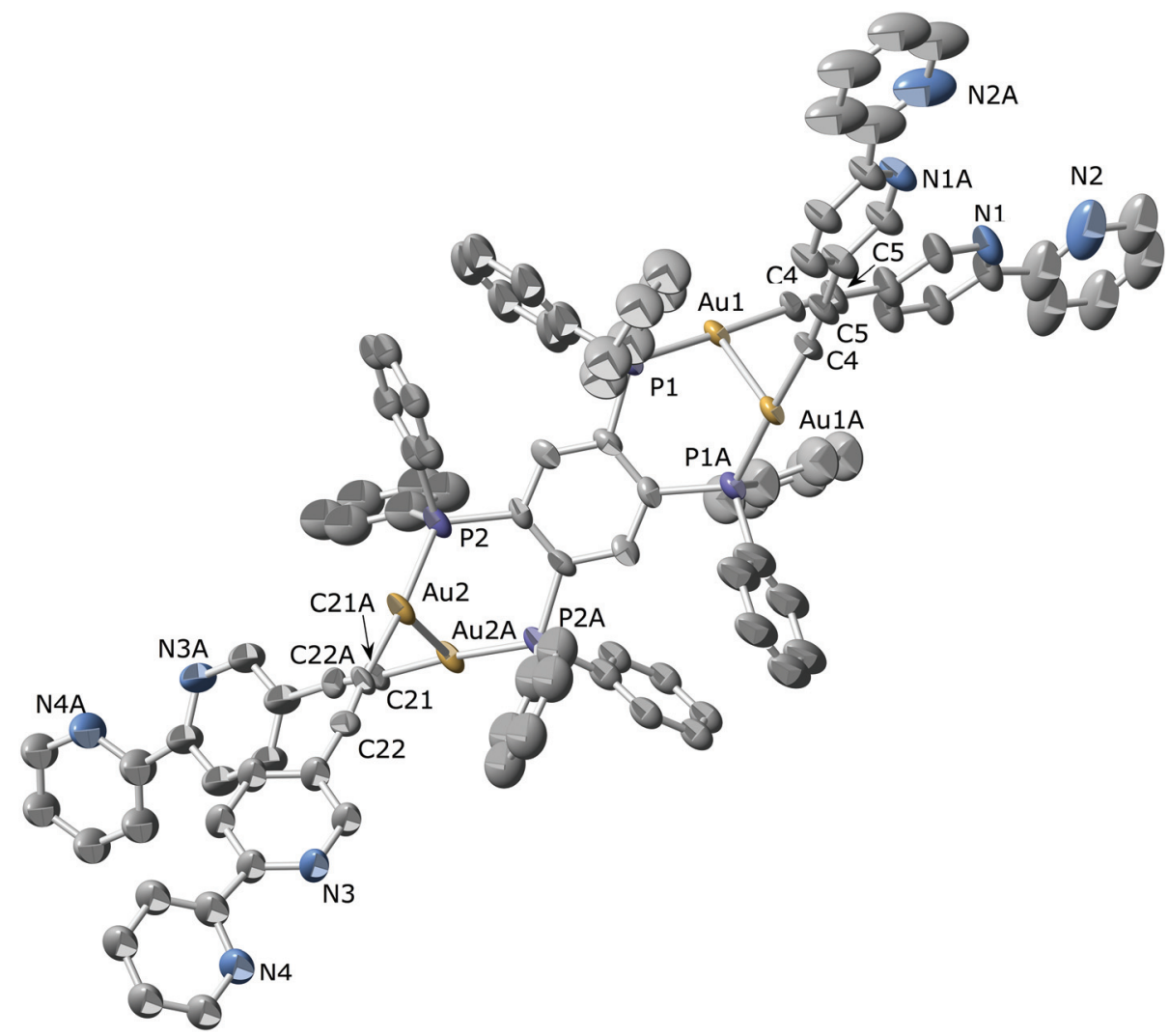

Fig. 2 Molecular structure of compound $\left[\mathrm{Au}_{4}\left(\mathrm{C} \equiv \mathrm{C}-\mathrm{C}_{10} \mathrm{H}_{7} \mathrm{~N}_{2}\right)_{4}\left(\mu_{4}\right.\right.$-tpbz)] (7). Thermal ellipsoids are drawn at the 30\% probability level. Hydrogen atoms have been omitted for clarity. Selected bond lengths ( $A$ ) and angles ( $\left.{ }^{\circ}\right)$ : $A u(1)-A u(1 A) 3.077(2), A u(2)-A u(2 A) 3.118(2), A u(1)-P(1) 2.290(6)$, $\mathrm{Au}(1)-C(4)$ 2.07(2), $\mathrm{Au}(2)-\mathrm{P}(2)$ 2.294(6), $\mathrm{Au}(2)-C(21)$ 2.03(2), C(4)-C(5) 1.13(3), C(21)-C(22) 1.19(3); $\mathrm{P}(1)-\mathrm{Au}(1)-\mathrm{C}(4)$ 176.9(6), $\mathrm{Au}(1)-\mathrm{C}(4)-\mathrm{C}(5)$ 174(2), $P(2)-A u(2)-C(21)$ 174.3(7), $A u(2)-C(21)-C(22)$ 175(2), C(4)-Au(1)-Au(1A) 102.9(6), $P(1)-A u(1)-A u(1 A) \quad 80.2(2), \quad C(21)-A u(2)-A u(2 A) \quad 107.1(7)$, $\mathrm{P}(2)-\mathrm{Au}(2)-\mathrm{Au}(2 \mathrm{~A}) 78.0(2)$.

is attributed to the stretching vibrations of the bipyridyl and terpyridyl moieties in the excited state.

Taking into account the observed vibrational spacings and previous reports dealing with $\mathrm{Au}(\mathrm{I})$ compounds containing the same aromatic chromophores, ${ }^{41,42,50,52}$ we assign these bands to intraligand transitions of $\left[\pi \rightarrow \pi^{*}-\left(\mathrm{C} \equiv \mathrm{C}-\mathrm{C}_{10} \mathrm{H}_{7} \mathrm{~N}_{2}\right)\right]$ or $\left[\pi \rightarrow \pi^{*}-\left(\mathrm{C} \equiv \mathrm{C}-\mathrm{C}_{15} \mathrm{H}_{10} \mathrm{~N}_{3}\right)\right]$. A lower intensity broad band or tail above $350 \mathrm{~nm}$ is also observed in all complexes and can be assigned to $\sigma^{*}(\mathrm{Au} \cdots \mathrm{Au})-\pi^{*}$ transitions according to theoretical calculations. ${ }^{75}$ The latter transitions have been found in related complexes recently reported by us. ${ }^{76-78}$ The vibronic structured bands are broad and not completely defined even at low concentrations, which are assigned to excitonic splitting where $\mathrm{Au} \cdots \mathrm{Au}$ and $\pi-\pi$ intramolecular stacking interactions are present between the arms of the dissolved complexes, as observed in previous studies carried out by our group. ${ }^{39}$ The extinction coefficients at the maximum of the absorption band increase with the number of chromophores present in the molecules. These are higher than those reported by analogous diphosphane derivatives, ${ }^{29,41,50}$ showing slight deviations of the monotonic increase due to differences in the intramolecular stacking interactions, where higher broadening leads to lower extinction coefficient at the maximum of the band.
All complexes are emissive at room temperature in solution and in the solid state. Emission spectra in dichloromethane solutions were recorded upon excitation of the samples at $330 \mathrm{~nm}$ (4-8) and $290 \mathrm{~nm}$ (9-13) (Fig. 3) and a dual emission was observed in all cases with maxima at $c a .400 \mathrm{~nm}$ and $530 \mathrm{~nm}$ for bipyridyl derivatives and at $c a .350 \mathrm{~nm}$ and $475 \mathrm{~nm}$ for terpyridyl complexes. The fact that complexes which contain the same alkynyl moiety present similar emission profiles, and comparing them with previous studies reported in the literature, ${ }^{40,41}$ let us attribute the recorded emissions to metal perturbed, alkynyl ligand based, ${ }^{1} \mathrm{IL}\left[\pi \rightarrow \pi^{*}\right]$ (higher energy emission) and ${ }^{3} \mathrm{IL}\left[\pi \rightarrow \pi^{*}\right]$ (lower energy emission) states. In all cases the presence of the Au heavy atom is expected to favour intersystem crossing and phosphorescence emission, which can be enhanced by the proximity of several $\mathrm{Au}$ atoms. The higher intensity of the phosphorescence band for the tetranuclear complex $\left[\mathrm{Au}_{4}\left(\mathrm{C} \equiv \mathrm{C}-\mathrm{C}_{10} \mathrm{H}_{7} \mathrm{~N}_{2}\right)_{4}\left(\mu_{4}\right.\right.$-tpbz) $](7)$ may result from a higher proximity between the arms through favouring $\mathrm{Au} \cdots \mathrm{Au}$ interactions, which in the case of the analogous compound $\left[\mathrm{Au}_{4}\left(\mathrm{C} \equiv \mathrm{C}-\mathrm{C}_{15} \mathrm{H}_{10} \mathrm{~N}_{3}\right)_{4}\left(\mu_{4}\right.\right.$-tpbz)] (12) could be hampered by the voluminous terpyridine ligand. As shown above, the X-ray molecular structure of compound 7 shows that all the gold centres of the compound are involved in 
Table 1 Absorption and emission data in $10^{-6} \mathrm{M}$ dichloromethane solution and solid-state emission at room temperature for compounds 4-13

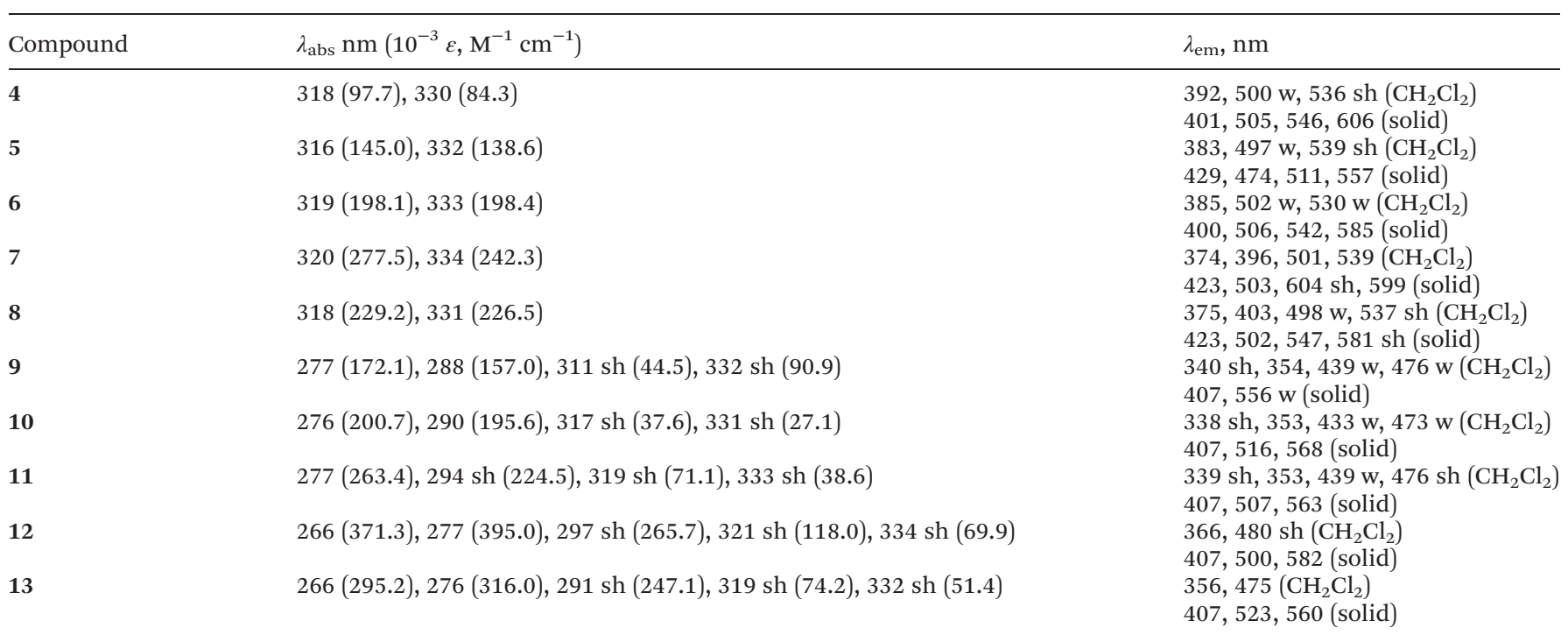
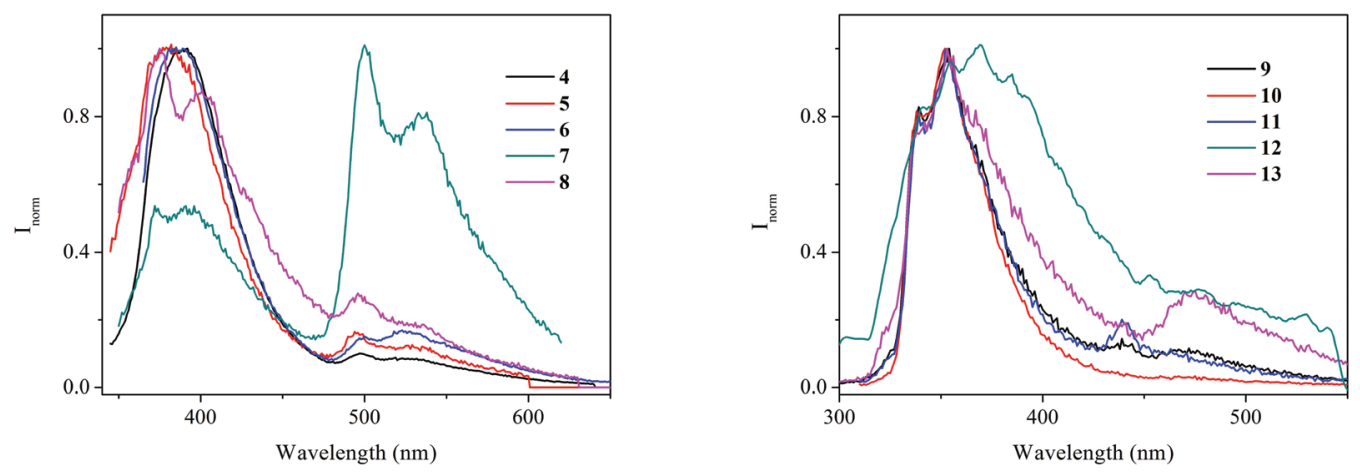

Fig. 3 Normalized emission spectra of $10^{-6} \mathrm{M}$ deoxygenated dichloromethane solutions of 4-8 (left) and 9-13 (right). $\lambda_{\text {exc }}(4-8)=330 \mathrm{~nm}$; $\lambda_{\text {exc }}$ $(9-13)=290 \mathrm{~nm}$.

rather short intramolecular aurophilic interactions. The emissions observed in the solid state at $298 \mathrm{~K}\left(\lambda_{\text {exc }}=370 \mathrm{~nm}\right.$ for $\mathbf{4 - 8}$ and $350 \mathrm{~nm}$ for 9-13) are comparable to that obtained in deoxygenated dichloromethane solutions.

\section{Titration studies}

As indicated in the Introduction, one of the main aims of this work was to obtain bipyridyl and terpyridyl functionalized polygold compounds able to coordinate to cationic metallic species. To exploit the potential of the titled compounds in this regard, we envisaged the evaluation of the cation-binding ability of the obtained complexes by solution titrations.

As a starting point, we report here studies of the interaction of the bipyridine-containing compounds 4-7 with cations such $\mathrm{Cu}^{+}$and $\mathrm{Zn}^{2+}$. The changes in the absorption and emission bands of the polynuclear alkynyl gold(I) compounds have been monitored in order to evaluate the cation-metallaligand interaction.

The addition of increasing amounts of $\left[\mathrm{Cu}\left(\mathrm{CH}_{3} \mathrm{CN}\right)_{4}\right] \mathrm{BF}_{4}$ to a $10^{-6} \mathrm{M}$ dichloromethane solution of the complexes 4-7 dis- plays, in all cases, a bathochromic shift of the maximum of the $\pi \rightarrow \pi^{*}$ absorption band of the bipyridyl moiety from $c a$. $330 \mathrm{~nm}$ (free complex) to ca. $350 \mathrm{~nm}$ (adduct). This behaviour is typical of the coordination of cations to the $\mathrm{N}, \mathrm{N}$-bidentate site of the bipyridine moiety and has been normally attributed to the transoid to cisoid isomerization of the heteroaromatic core $^{79-81}$ (Fig. 4 for compound 5 and Fig. S47-S49 for compounds 4, 6 and 7 in the ESI $\dagger$ ).

The titrations showed the absence of well-defined isosbestic points, pointing to the presence of at least two new absorbing species formed during the addition of the $\mathrm{Cu}^{+}$cation. The fitting procedure of the obtained data performed with a nonlinear least-squares algorithm implemented in the Specfit software $^{82}$ allowed the calculation of the stability constants $\left(\beta_{1 n}\right)$ for the studied equilibria (Table 2). In the case of metallaligands with three arms the coordination of $\mathrm{Cu}^{+}$to the different bipyridine units gave rise to the coexistence of either $\left[\mathbf{4} \cdot 2 \mathrm{Cu}^{+}\right]^{2+}$ and $\left[\mathbf{4} \cdot 3 \mathrm{Cu}^{+}\right]^{3+}$ or $\left[5 \cdot 1 \mathrm{Cu}^{+}\right]^{+},\left[\mathbf{5} \cdot 2 \mathrm{Cu}^{+}\right]^{2+}$ and $\left[5 \cdot 3 \mathrm{Cu}^{+}\right]^{3+}$ (Fig. 4). In the case of tetraphos and tpbz derivatives 6 and 7 , the fitting analysis was consistent with the formation of 

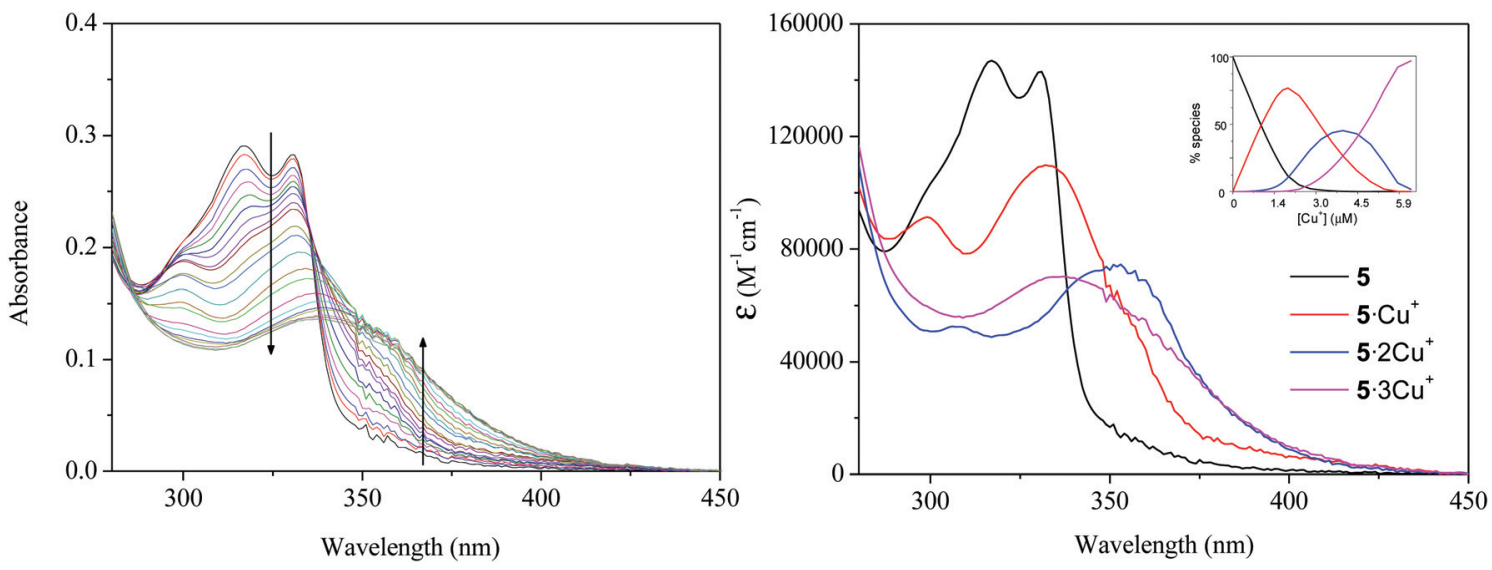

Fig. 4 Absorption spectra of a $10^{-6} \mathrm{M}$ dichloromethane solution of 5 upon addition of different amounts of $\left[\mathrm{Cu}\left(\mathrm{CH}_{3} \mathrm{CN}_{4}\right] \mathrm{BF} \mathrm{F}_{4}(\mathrm{left})\right.$. Spectra of individual species obtained from Specfit factorial analyses (right). Inset shows calculated speciation of the species formed upon titration.

Table 2 Calculated stability constants of studied complexes

\begin{tabular}{lllll}
\hline Ligand/cation & $\log \left(\beta_{11}\right)$ & $\log \left(\beta_{12}\right)$ & $\log \left(\beta_{13}\right)$ & $\log \left(\beta_{14}\right)$ \\
\hline $\mathbf{4} / \mathbf{C u}^{+}$ & & $15 \pm 1$ & $20 \pm 1$ & \\
$\mathbf{5} / \mathbf{C u}^{+}$ & $10 \pm 1$ & $19 \pm 1$ & $28 \pm 1$ & \\
$\mathbf{6} / \mathbf{C u}^{+}$ & & $20 \pm 1$ & & $35 \pm 1$ \\
$\mathbf{7 / C \mathbf { C u } ^ { + }}$ & & $15 \pm 1$ & & $28 \pm 1$ \\
$\mathbf{4} / \mathbf{Z n}^{2+}$ & & & $15 \pm 1$ &
\end{tabular}

species with a paired number of coordinated $\mathrm{Cu}^{+}$i.e. $\left[6 / 7 \cdot 2 \mathrm{Cu}^{+}\right]^{2+}$ and $\left[6 / 7 \cdot 4 \mathrm{Cu}^{+}\right]^{4+}$ indicating that, in this case, symmetric coordination is favoured over other stoichiometric possibilities.

Emission titrations gave very interesting profiles. As can be seen in Fig. 5 for compound 5 and in Fig. S47-S49 in the ESI $\dagger$ for the remaining compounds, the addition of copper(I) salt to a dichloromethane solutions of compounds 4-7 induced a decrease in both fluorescence and phosphorescence bands of the hosts.

Similar behaviour has been reported for $\mathrm{Cu}^{+}$titrations on organic fluorophores that contain appended 5-ethynyl-2,2'bipyridyl fragments. $^{83}$ In contrast, the emission spectra

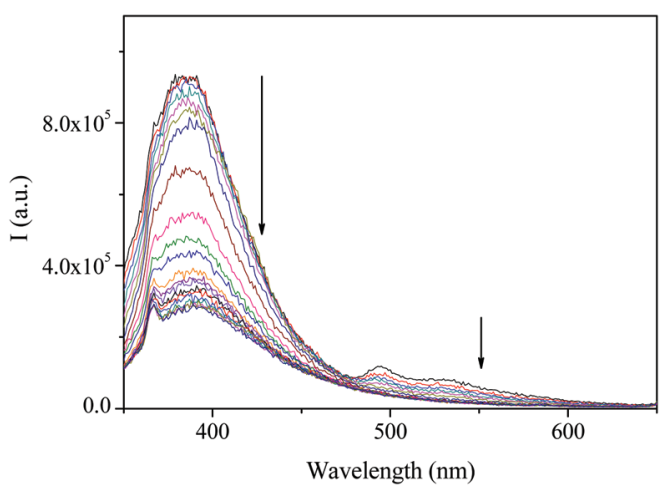

Fig. 5 Emission spectra of a $10^{-6} \mathrm{M}$ dichloromethane solution of 5 upon addition of different amounts of $\left[\mathrm{Cu}\left(\mathrm{CH}_{3} \mathrm{CN}\right)_{4}\right] \mathrm{BF}_{4}$. recorded for the 1:1 complex after adding 1 equivalent of $\left[\mathrm{Cu}\left(\mathrm{CH}_{3} \mathrm{CN}\right)_{4}\right] \mathrm{BF}_{4}$ in deoxygenated samples display an increase of both fluorescence and phosphorescence emission bands (Fig. S50 in the ESI $\dagger$ ), which could be related to the presence of an equilibrium between singlet and triplet states as observed in systems that present activated delayed fluorescence.

Additionally, the possibility of interaction with other cations able to coordinate to bipyridyl units, such as $\mathrm{Zn}^{2+}$, was envisaged. Preliminary experiments carried out with $\mathbf{4}$ as a representative compound of these series showed changes in absorption and emission spectra that present noteworthy differences from those obtained with $\mathrm{Cu}^{+}$(Fig. S51 in the ESI $\dagger$ ). On the one hand, a progressive decrease of the host absorption bands with a concomitant development of a longer wavelength transition was observed. The observation of a welldefined isosbestic point at $338 \mathrm{~nm}$ is indicative of a neat interconversion between the uncomplexed and complexed states, which contrasts with the equilibrium among various species found in the case of $\mathrm{Cu}^{+}$addition. Fitting of the titration data $^{82}$ gave a single stability constant value (Table 2) that corresponds to the formation of $\left[4 \cdot 3 \mathrm{Zn}^{2+}\right]^{6+}$ as unique species. On the other hand, the emission titration results in a redshifted and clear enhancement (15-fold) of the fluorescence band of compound $\mathbf{4}$, which is in agreement with a bindinginduced conformational restriction of the bipyridine moiety by $\mathrm{Zn}^{2+}$ chelation. ${ }^{84}$

\section{Conclusions}

An improved method for obtaining polyphosphanyl benzene phosphanes has been developed.

Trinuclear and tetranuclear phosphane alkynyl gold(I) systems with appended bipyridyl or terpyridyl moieties have been obtained using two different methods. While the reaction between the gold(I) polymeric species $[\mathrm{Au}(\mathrm{C} \equiv \mathrm{C}-\mathrm{R})]_{n}$ and the appropriate polyphosphane (polymer method) afforded the 
desired compounds in good yield in all the cases, the "acac method" implied long reaction times and only allowed the synthesis of a limited number of complexes due to the impossibility of isolating the appropriate polyacetylacetonate precursor. In spite of this, the new isolated poly "acac" species $\left[\mathrm{Au}_{3}(\mathrm{acac})_{3}\left(\mu_{3}\right.\right.$-triphosphane) $]$ (triphosphane $=$ triphos and triphosph) and $\left[\mathrm{Au}_{4}(\mathrm{acac})_{4}\left(\mu_{4}\right.\right.$-tetraphos $\left.)\right]$ are reactive species that can be widely used as a precursors in organometallic synthesis.

All the prepared compounds are luminescent at room temperature in solution and in the solid state and exhibit dual emissions that have been assigned to gold perturbed, alkynyl ligand based, ${ }^{1} \mathrm{IL}\left[\pi \rightarrow \pi^{*}\right]$ and ${ }^{3} \mathrm{IL}\left[\pi \rightarrow \pi^{*}\right]$ states.

Dissimilar behaviour has been found on studying the absorption and emission properties of the synthesized bipyridyl metallaligands upon complexation with closed-shell cations like $\mathrm{Cu}^{+}$and $\mathrm{Zn}^{2+}$. Absorption titrations showed a clean process for $\mathrm{Zn}^{2+}$ while complex equilibria that involve the simultaneous formation of various absorbing species are detected for $\mathrm{Cu}^{+}$. In emission titrations, a quenching or an enhancement of the fluorescence in the resulting supramolecular aggregates are observed on adding $\mathrm{Cu}^{+}$or $\mathrm{Zn}^{2+}$, respectively.

Finally, we have demonstrated that the species reported here have a great potential as chelating or bridging polytopic metallaligands with interesting photophysical properties. For this reason, further studies of the reactivity of the complexes reported here against a wide range of metallic cations as well as of the properties exhibited by the resulting species are currently in progress.

\section{Experimental section}

\section{General methods}

All manipulations were performed under a pre-purified nitrogen atmosphere using Schlenk-tube techniques. Solvents were dried by standard methods and distilled under nitrogen immediately prior to use, or alternatively from a Solvent Purification System (Innovative Technologies).

Literature methods were used to prepare $[\mathrm{AuCl}(\mathrm{tht})],{ }^{85}$ $\mathrm{Tl}(\mathrm{acac}),{ }^{86} \quad\left[\mathrm{Au}\left(\mathrm{C} \equiv \mathrm{C}-\mathrm{C}_{10} \mathrm{H}_{7} \mathrm{~N}_{2}\right)\right]_{n}{ }^{41} \quad$ 5-trimethylsilylethynyl2,2'-bipyridine, ${ }^{87} 4^{\prime}$-ethynyl-2,2': $6^{\prime}, 2^{\prime \prime}$-terpyridine, ${ }^{87,88}$ tetrakis (diphenylphosphanylmethyl)methane (tetraphos), ${ }^{70} \quad N, N$, $N^{\prime}, N^{\prime}$-tetra(diphenylphosphanylmethyl)-1,2-ethylenediamine (dppeda) $,{ }^{89,90}\left[(\mathrm{AuCl})_{3}\left(\mu_{3}\right.\right.$-triphos $\left.)\right],{ }^{91}\left[(\mathrm{AuCl})_{3}\left(\mu_{3}\right.\right.$-triphosph $\left.)\right],{ }^{92}$ $\left[(\mathrm{AuCl})_{4}\left(\mu_{4}\right.\right.$-tetraphos $\left.)\right],{ }^{70}$ and $\left[(\mathrm{AuCl})_{4}\left(\mu_{4}\right.\right.$-dppeda $\left.)\right]{ }^{93}$ All other reagents were obtained from commercial suppliers and used as received.

Infrared spectra were recorded on a FT-IR 520 Nicolet Spectrophotometer. ${ }^{1} \mathrm{H}$ NMR $(\delta(\mathrm{TMS})=0.0 \mathrm{ppm}),{ }^{31} \mathrm{P}\left\{{ }^{1} \mathrm{H}\right\}$ NMR $\left(\delta\left(85 \% \mathrm{H}_{3} \mathrm{PO}_{4}\right)=0.0 \mathrm{ppm}\right)$ and ${ }^{13} \mathrm{C}\left\{{ }^{1} \mathrm{H}\right\} \operatorname{NMR}(\delta(\mathrm{TMS})=$ $0.0 \mathrm{ppm}$ ) spectra were obtained at $250,300,400$ or $500 \mathrm{MHz}$ with Varian and Bruker spectrometers at $25{ }^{\circ} \mathrm{C}$ unless otherwise stated. Elemental analyses of $\mathrm{C}, \mathrm{H}$, and $\mathrm{N}$ were carried out at the Centres Científics i Tecnològics (Universitat de
Barcelona). ESI-MS mass spectra were recorded on a LC/MSD TOF Agilent Technologies 61969A spectrometer in $\mathrm{H}_{2} \mathrm{O}: \mathrm{CH}_{3} \mathrm{CN} \quad(1: 1)$ solutions. Absorption spectra were recorded on a Varian Cary 100 Bio spectrophotometer. Emission and excitation spectra were recorded on a HoribaJobin-Yvon SPEX Nanolog spectrofluorimeter. Solutions were prepared with spectroscopic grade solvents. Titrations were carried out by addition of aliquots of $10^{-4} \mathrm{M}$ solutions of the cations prepared in dichloromethane to the host solution $\left(10^{-6} \mathrm{M}\right.$ in dichloromethane). Absorption and emission spectra were measured after each addition.

\section{X-Ray structure determination}

Crystal data for complexes 6 and 7 are presented in the ESI (Table S1†).

Data for $\left[\mathrm{Au}_{4}\left(\mathrm{C} \equiv \mathrm{C}-\mathrm{C}_{10} \mathrm{H}_{7} \mathrm{~N}_{2}\right)_{4}\left(\mu_{4}\right.\right.$-tetraphos $\left.)\right]$ (6) were collected at $120.0 \mathrm{~K}$ on a dual source Rigaku Oxford SuperNova diffractometer equipped with an Atlas detector using mirrormonochromated $\mathrm{Cu}-\mathrm{K} \alpha$ radiation $(\lambda=1.54184 \AA$ A). The data collection and reduction were done using the program CrysAlisPro ${ }^{94}$ and the intensities were corrected for absorption using the Gaussian face-index absorption correction method. ${ }^{94}$ The structure was solved with direct methods (SHELXS) ${ }^{95,96}$ and refined by full-matrix least squares on $F^{2}$ using the OLEX2 $2{ }^{97}$ which utilizes the SHELXL module. ${ }^{95,96}$ No attempt was made to locate the hydrogens for disordered organic molecules in the unit cell. Constraint (EADP) and restraint (ISOR) commands are used where appropriate to suppress the alerts for large displacement parameter in checkcif. For a few aromatic rings and $\mathrm{C}-\mathrm{C}$ bond distances, constraint (AFIX) and restraint (DFIX) commands were to suppress Hirshfeld differences for non-hydrogen atoms in A and B-alerts. Two of the $\mathrm{Au}$-atoms are severely disordered, and attempts to resolve high electron residual density create additional A and B-alerts. Finally, continuous four Fourier cycles of refinement were performed until the convergence was achieved. The final refinement convergence was achieved at $R_{1}=0.1094$ and $\mathrm{w} R_{2}=$ 0.2561 for intensities $I>2(I)$ with the largest peak/hole in the final difference map as 8.516/-3.240 e $\AA^{-3}$.

The intensity data sets for $\left[\mathrm{Au}_{4}\left(\mathrm{C} \equiv \mathrm{C}-\mathrm{C}_{10} \mathrm{H}_{7} \mathrm{~N}_{2}\right)_{4}\left(\mu_{4}\right.\right.$-tpbz $\left.)\right]$ (7) were collected at $200 \mathrm{~K}$ on a Bruker-Nonius KappaCCD diffractometer equipped with an Oxford Cryostream 700 unit. The structure was solved, by using the WINGX package, ${ }^{98}$ by direct methods (SHELXS-2013) ) $^{95,96,99}$ and refined by leastsquares against $F^{2}$ (SHELXL-2014).$^{95,96,99}$ All the hydrogen atoms were positioned geometrically and refined by using a riding model. Crystals of compound 7 diffracted very weakly, and only data collections up to $\theta=23^{\circ}$ could be performed. The crystals of compound 7 crystallized with a huge number of solvent molecules, but it was not possible to obtain sensible chemical models for them. The Squeeze procedure of the PLATON $^{100}$ package was employed to remove the contribution of that electronic density to the structure factors, obtaining a solvent accessible volume equivalent to $21 \%$ of the unit cell volume. EADP constraints were applied to bipyridine and phenyl ring atoms to suppress the alerts for large displacement 
parameter in checkcif. The final refinement convergence was achieved at $R_{1}=0.092$ and $\mathrm{w} R_{2}=0.223$ for intensities $I>2(I)$ with the largest peak/hole in the final difference map as $3.139 /-1.577$ e $\AA^{-3}$.

\section{Synthesis and characterization}

Preparation of 5-ethynyl-2,2'-bipyridine. The compound was prepared by a modified procedure of the deprotection of the trimethylsilylethynyl group described by Ziessel in ref. 87 .

To a solution of $500 \mathrm{mg}$ of 5-trimethylsilylethynyl-2,2'-bipyridine (obtained by a copper-catalyzed Sonogashira coupling) ${ }^{87}$ in $50 \mathrm{ml}$ of $\mathrm{MeOH}, \mathrm{KF}(140 \mathrm{mg}, 2.41 \mathrm{mmol})$ was added and the mixture was stirred overnight at room temperature. The resulting suspension was evaporated to dryness under vacuum and the residue was chromatographed on silica and eluted with $\mathrm{CH}_{2} \mathrm{Cl}_{2} / \mathrm{MeOH}(100: 2)$ to yield a darkish solid that contains copper as impurity. The solid was dissolved in $100 \mathrm{~mL}$ of chloroform acidified with a few drops of $\mathrm{HCl}_{(\mathrm{aq})}$ and the mixture was stirred for 3 hours at RT. After this time the red suspension was filtered through Celite and extracted $(3 \times$ $100 \mathrm{~mL}$ ) with $15.5 \% \mathrm{NH}_{3(\mathrm{aq})}$ saturated with EDTA. The organic layer was separated, washed with brine and dried over $\mathrm{MgSO}_{4}$. The resulting solution was evaporated to dryness and the crude product was purified by vacuum sublimation at $70^{\circ} \mathrm{C}$ to yield a white crystalline solid, which gave analytical data identical to those previously reported. ${ }^{87}$ Yield: (303 mg, 85\%).

Preparation of 1,3,5-tris(diphenylphosphanyl)benzene (triphosph) and 1,2,4,5-tetrakis(diphenylphosphanyl)benzene (tpbz). The syntheses of 1,3,5-tris(diphenylphosphanyl) benzene and 1,2,4,5-tetrakis(diphenylphosphanyl)benzene were based on that described for 1,2(diphenylphosphanyl) benzene. ${ }^{62}$ From $0.75 \mathrm{~mL}$ of the starting fluorinated compounds (7.2 mmol of 1,3,5-trifluorobenzene and $6.7 \mathrm{mmol}$ of 1,2,4,5-tetrafluorobenzene), $2.19 \mathrm{~g}$ (48\%) and $3.06 \mathrm{~g}$ (56\%) of the above indicated tri- and tetraphosphanes were obtained, respectively. Analytical data were identical to those previously reported. ${ }^{101}$

Preparation of $\left[\mathrm{Au}\left(\mathrm{C} \equiv \mathbf{C}-\mathbf{C}_{\mathbf{1 5}} \mathbf{H}_{\mathbf{1 0}} \mathbf{N}_{\mathbf{3}}\right)\right]_{n}$. The synthesis of $\left[\mathrm{Au}\left(\mathrm{C} \equiv \mathrm{C}-\mathrm{C}_{15} \mathrm{H}_{10} \mathrm{~N}_{3}\right)\right]_{n}$ was based on that described for $[\mathrm{Au}(\mathrm{C} \equiv \mathrm{C}-$ $\left.\left.\mathrm{C}_{10} \mathrm{H}_{7} \mathrm{~N}_{2}\right)\right]_{n} \cdot{ }^{41}[\mathrm{AuCl}(\mathrm{tht})](125 \mathrm{mg}, 0.39 \mathrm{mmol})$ and recently distilled $\mathrm{NEt}_{3}(0.16 \mathrm{~mL}, 1.17 \mathrm{mmol})$ were added to a solution of 4'-ethynyl-2,2':6',2"-terpyridine (100 mg, $0.39 \mathrm{mmol})$ in $10 \mathrm{ml}$ of $\mathrm{CH}_{2} \mathrm{Cl}_{2}$. The mixture was protected from light and stirred for $2 \mathrm{~h}$. The obtained yellowish suspension was concentrated to dryness under vacuum giving a yellow solid that was washed subsequently with $\mathrm{MeOH}$ and $\mathrm{Et}_{2} \mathrm{O}$ and dried under vacuum. Yield (124 mg, 70\%). Anal. found: C, 45.70; H, 2.33; N, 9.35; calc. for $\mathrm{C}_{17} \mathrm{H}_{10} \mathrm{AuN}_{3}$ : C, 45.05; H, 2.22; N, 9.27\%. IR $\nu_{\max } / \mathrm{cm}^{-1}$ $2119(\mathrm{C} \equiv \mathrm{C})$.

Preparation of $\left[\mathrm{Au}_{3}(\mathrm{acac})_{3}\left(\boldsymbol{\mu}_{3}\right.\right.$-triphos $\left.)\right]$ (1). To an acetone solution of $\left[(\mathrm{AuCl})_{3}\left(\mu_{3}\right.\right.$-triphos $\left.)\right](200 \mathrm{mg}, 0.16 \mathrm{mmol})$, solid $\mathrm{Tl}(\mathrm{acac})$ (160 mg, $0.53 \mathrm{mmol}$ ) was added. The resulting mixture was protected from light and stirred for $48 \mathrm{~h}$. The obtained suspension was concentrated to dryness and the residue was extracted with dichloromethane $(3 \times 5 \mathrm{~mL})$. The combined extracts were concentrated under vacuum $(5 \mathrm{~mL})$ and $n$-hexane was added to precipitate a white solid. Yield (172 mg, 71\%). IR $\nu_{\max } / \mathrm{cm}^{-1} 1648,1622$ (acac); 1504, 1436, 1096 (triphos). ${ }^{1} \mathrm{H}-\mathrm{NMR}\left(300 \mathrm{MHz}, \mathrm{CDCl}_{3}, 298 \mathrm{~K}\right)$ 7.80-7.35 (30H, br s, $\mathrm{PPh}_{2}$ ), 3.09 (6H, d, ${ }^{2} J(H-P)$ 10.8, $\left.\mathrm{CH}_{2}-\mathrm{P}\right), 2.33\left(3 \mathrm{H}, \mathrm{d},{ }^{3} J(H-P)\right.$ 11.4, $\mathrm{CO}-\mathrm{CH}-\mathrm{CO}), 1.94$ (18H, s, $\left.\mathrm{CH}_{3}-\mathrm{CO}\right), 1.01$ (3H, s, $\left.\mathrm{CH}_{3}-\mathrm{C}\right) .{ }^{31} \mathrm{P}$ $\left\{{ }^{1} \mathrm{H}\right\}$-NMR (121.4 MHz, $\left.\mathrm{CDCl}_{3}, 298 \mathrm{~K}\right) 24.9\left(\mathrm{~s}, \mathrm{PPh}_{2}\right)$.

Preparation of $\left[\mathrm{Au}_{3}(\mathrm{acac})_{3}\left(\boldsymbol{\mu}_{3}\right.\right.$-triphosph)] (2). To an acetone solution of $\left[(\mathrm{AuCl})_{3}\left(\mu_{3}\right.\right.$-triphos $\left.)\right](226 \mathrm{mg}, 0.17 \mathrm{mmol})$, solid $\mathrm{Tl}(\mathrm{acac})$ (170 mg, $0.56 \mathrm{mmol}$ ) was added. The obtained mixture was protected from light and stirred for 1 week. The resulting suspension was filtered and the solid was extracted with acetone $(3 \times 5 \mathrm{~mL})$. The combined extracts together with the filtrate were concentrated to dryness. The remaining solid was dissolved in the minimum amount of dichloromethane and $n$-hexane was added to precipitate a beige solid. Yield $(130 \mathrm{mg}$, $50 \%$ ). Anal. found: C, 44.99; $\mathrm{H}, 3.52$; calc. for $\mathrm{C}_{57} \mathrm{H}_{54} \mathrm{Au}_{3} \mathrm{O}_{6} \mathrm{P}_{3}$ : C, 45.07; H, 3.58\%. IR $\nu_{\max } / \mathrm{cm}^{-1} 1647,1631$ (acac); 1504, 1439, 1096 (triphosph). ${ }^{1} \mathrm{H}-\mathrm{NMR}\left(300 \mathrm{MHz}, \mathrm{CDCl}_{3}, 298 \mathrm{~K}\right) 7.58-7.34$ $\left(33 \mathrm{H}, \mathrm{m}, \mathrm{PPh}_{2}+\mathrm{P}-\mathrm{C}_{6} \mathrm{H}_{3}-\mathrm{P}\right), 2.61\left(3 \mathrm{H}, \mathrm{d},{ }^{3} J(H-P)\right.$ 11.1, CO-CHCO), 2.12 (18H, s, $\left.\mathrm{CH}_{3}-\mathrm{CO}\right) .{ }^{31} \mathrm{P}\left\{{ }^{1} \mathrm{H}\right\}-\mathrm{NMR}$ (121.4 MHz, $\mathrm{CDCl}_{3}$, $298 \mathrm{~K}) 42.6\left(\mathrm{~s}, \mathrm{PPh}_{2}\right)$.

Preparation of $\left[\mathrm{Au}_{4}(\mathrm{acac})_{4}\left(\mu_{4}\right.\right.$-tetraphos)] (3). Compound 3 was synthesized following an analogous procedure to that described for compound 2. From (300 mg, $0.17 \mathrm{mmol})$ of $\left[(\mathrm{AuCl})_{4}\left(\mu_{3}\right.\right.$-tetraphos $\left.)\right]$ and $(230 \mathrm{mg}, 0.76 \mathrm{mmol}) \mathrm{Tl}(\mathrm{acac})$ and a reaction time of $72 \mathrm{~h}$ compound 3 was obtained as a white solid. Yield (187 mg, 55\%). Anal. found: C, 43.41; H, 3.80; calc. for $\mathrm{C}_{73} \mathrm{H}_{76} \mathrm{Au}_{4} \mathrm{O}_{8} \mathrm{P}_{4}: \mathrm{C}, 43.99 ; \mathrm{H}, 3.84 \%$. IR $\nu_{\max } / \mathrm{cm}^{-1} 1652$, 1622 (acac); 1504, 1435, 1096 (tetraphos). ${ }^{1} \mathrm{H}-\mathrm{NMR}(300 \mathrm{MHz}$, $\left.\mathrm{CDCl}_{3}, 298 \mathrm{~K}\right)$ 7.70-6.80 (br m, $\left.\mathrm{PPh}_{2}+\mathrm{CHCl}_{3}\right), 3.11(12 \mathrm{H}$, br s, $\left.\mathrm{CO}-\mathrm{CH}-\mathrm{CO}+\mathrm{C}-\mathrm{CH}_{2}-\mathrm{P}\right), 2.03\left(24 \mathrm{H}\right.$, br s, $\left.\mathrm{CH}_{3}-\mathrm{CO}\right) .{ }^{31} \mathrm{P}\left\{{ }^{1} \mathrm{H}\right\}-$ NMR (121.4 MHz, $\left.\mathrm{CDCl}_{3}, 298 \mathrm{~K}\right) 22.8\left(\mathrm{~s}, \mathrm{PPh}_{2}\right)$.

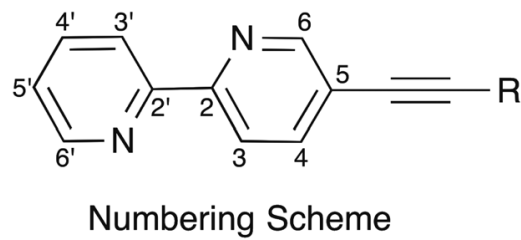

\section{Preparation of $\left[\mathrm{Au}_{3}\left(\mathrm{C} \equiv \mathrm{C}-\mathrm{C}_{10} \mathbf{H}_{7} \mathbf{N}_{2}\right)_{3}\left(\boldsymbol{\mu}_{3}\right.\right.$-triphos $\left.)\right]$ (4)}

Polymer method. To a suspension of $\left[\mathrm{Au}\left(\mathrm{C} \equiv \mathrm{C}-\mathrm{C}_{10} \mathrm{H}_{7} \mathrm{~N}_{2}\right)\right]_{n}$ (50 $\mathrm{mg}, 0.13 \mathrm{mmol})$ in $\mathrm{CH}_{2} \mathrm{Cl}_{2}(15 \mathrm{~mL})$, the stoichiometric amount of solid triphos $(28 \mathrm{mg}, 0.04 \mathrm{mmol})$ was added and the mixture was stirred for $2 \mathrm{~h}$. The resulting pale yellow solution was concentrated $(5 \mathrm{~mL})$ and $n$-hexane was added to precipitate a white solid, which was filtered off, washed with $n$-hexane $(3 \times 5 \mathrm{~mL})$ and dried in vacuo. Yield (53 mg, 75\%).

acac method. To a solution of $\left[\mathrm{Au}_{3}(\mathrm{acac})_{3}\left(\mu_{3}\right.\right.$-triphos $\left.)\right]$ (1) (75 mg, $0.05 \mathrm{mmol})$ in $\mathrm{CH}_{2} \mathrm{Cl}_{2}(15 \mathrm{~mL})$, a stoichiometric amount of 5-ethynyl-2,2'-bipyridine (27 mg, $0.15 \mathrm{mmol}$ ) was added. The solution was stirred for $4 \mathrm{~h}$ and concentrated to $5 \mathrm{~mL}$ in vacuo. Subsequent addition of $n$-hexane caused the precipitation of a white microcrystalline solid, which was filtered off, washed with $n$-hexane $(3 \times 5 \mathrm{~mL})$ and dried in vacuo. Yield (44 mg, 50\%). 
Anal. found: C, 52.89; H, 3.42; N, 4.81; calc. for $\mathrm{C}_{77} \mathrm{H}_{60} \mathrm{Au}_{3} \mathrm{~N}_{6} \mathrm{P}_{3}$ : C, 52.75; H, 3.45; N, 4.79\%. IR $\nu_{\max } / \mathrm{cm}^{-1} 2116$ $(\mathrm{C} \equiv \mathrm{C}) ; 1429,1097$ (triphos). ${ }^{1} \mathrm{H}-\mathrm{NMR}\left(400 \mathrm{MHz}, \mathrm{CDCl}_{3}, 298 \mathrm{~K}\right)$ $8.72(3 \mathrm{H}, \mathrm{m}, 6-\mathrm{H}), 8.67$ (3H, ddd, $\left.J(H-H) 4.8,1.8,0.8,6^{\prime}-\mathrm{H}\right)$, 8.38 (3H, dt, $J(H-H)$ 8.0, 1.0, 3'-H), 8.31 (dd, $J(H-H)$ 8.2, 0.7, 3-H), 7.96-7.89 (12H, m, $\left.\mathrm{PPh}_{2}\right), 7.82(3 \mathrm{H}, \mathrm{dd}, J(H-H)$ 8.4, 2.4, $4-\mathrm{H}), 7.81\left(3 \mathrm{H}, \mathrm{td}, J(H-H)=7.5,1.8,4^{\prime}-\mathrm{H}\right), 7.46-7.43(18 \mathrm{H}, \mathrm{br}$ m, $\left.\mathrm{PPh}_{2}\right), 7.29$ (3H, ddd, $\left.J(H-H) 7.5,4.8,1.2,5^{\prime}-\mathrm{H}\right), 3.46(6 \mathrm{H}, \mathrm{d}$, $\left.{ }^{2} J(H-P) \quad 10.9, \quad \mathrm{CH}_{2}\right), \quad 0.89 \quad\left(3 \mathrm{H}, \quad \mathrm{s}, \quad \mathrm{CH}_{3}\right) . \quad{ }^{31} \mathrm{P}\left\{{ }^{1} \mathrm{H}\right\}-\mathrm{NMR}$ (121.4 MHz, $\left.\mathrm{CDCl}_{3}, 298 \mathrm{~K}\right) 25.4\left(\mathrm{~s}, \mathrm{PPh}_{2}\right) .{ }^{13} \mathrm{C}\left\{{ }^{1} \mathrm{H}\right\}-\mathrm{NMR}$ (100.6 MHz, $\left.\mathrm{CDCl}_{3}, 298 \mathrm{~K}\right)$ 156.0, 153.6 (C2 + C2'), 152.5 (C6), 149.4 (s, C6'), 139.9 (s, C4), 138.4 (d, ${ }^{2} J(C-P)$ 140, P-Au- $C \equiv \mathrm{C}$ ), 137.0 (C4'), 134.1 (d, ${ }^{2} J(C-P)$ 14, $\left.\mathrm{C}_{\text {ortho }} \mathrm{Ph}\right), 132.1\left(\mathrm{C}_{\text {para }} \mathrm{Ph}\right)$, $131.0\left(\mathrm{~d},{ }^{1} J(C-P)\right.$ 56, $\left.\mathrm{C}_{i p s o} \mathrm{Ph}\right), 129.6\left(\mathrm{~d},{ }^{3} J(C-P) 12, \mathrm{C}_{\text {meta }} \mathrm{Ph}\right)$, 123.7 (C5'), 122.3 (C5), 121.3 (C3'), 120.3 (C3), 101.4 (d, ${ }^{3} J(C-P)$ 26, $\mathrm{P}-\mathrm{Au}-\mathrm{C} \equiv C), 42.8$ (d, $\left.{ }^{1} J(C-P) 31, \mathrm{CH}_{2}\right), 39.0$ ( $\mathrm{C}_{\mathrm{q}}$-triphos), $30.7\left(\mathrm{CH}_{3}\right)$. MS ESI $(+) m / z 1573.2\left(100 \%,\left[\mathrm{M}-\mathrm{C}_{12} \mathrm{H}_{7} \mathrm{~N}_{2}\right]^{+}\right.$, calc. 1573.2), $697.1\left(6 \%,\left[\mathrm{M}-2\left(\mathrm{C}_{12} \mathrm{H}_{7} \mathrm{~N}_{2}\right)\right]^{2+}\right.$, calc. 697.1$) 877.2$ $\left(85 \%,\left[\mathrm{M}+2 \mathrm{H}^{+}\right]^{2+}\right.$, calc. 877.2$), 585.1\left(8 \%,\left[\mathrm{M}+3 \mathrm{H}^{+}\right]^{3+}\right.$, calc. 585.1).

Preparation of $\left[\mathrm{Au}_{3}\left(\mathrm{C} \equiv \mathrm{C}-\mathrm{C}_{10} \mathrm{H}_{7} \mathbf{N}_{2}\right)_{3}\left(\boldsymbol{\mu}_{3}\right.\right.$-triphosph $\left.)\right]$ (5). Compound $\mathbf{5}$ was successfully synthesized following analogous procedures to those described for compound 4 .

Polymer method. From $(50 \mathrm{mg}, 0.13 \mathrm{mmol})$ of $[\mathrm{Au}(\mathrm{C} \equiv \mathrm{C}-$ $\left.\left.\mathrm{C}_{10} \mathrm{H}_{7} \mathrm{~N}_{2}\right)\right]_{n}$ and (28 mg, $0.04 \mathrm{mmol}$ ) of triphosph. Yield (50 mg, 71\%).

acac method. From $(76 \mathrm{mg}, 0.05 \mathrm{mmol})$ of $\left[\mathrm{Au}_{3}(\mathrm{acac})_{3}\left(\mu_{3}\right.\right.$-triphosph)] (2) and (27 mg, $0.15 \mathrm{mmol}$ ) of 5-ethynyl-2,2'-bipyridine and a reaction time of $6 \mathrm{~h}$. Yield (45 mg, 51\%).

Anal. found: $\mathrm{C}, 53.23 ; \mathrm{H}, 3.03 ; \mathrm{N}, 4.80 ;$ calc. for $\mathrm{C}_{78} \mathrm{H}_{54} \mathrm{Au}_{3} \mathrm{~N}_{6} \mathrm{P}_{3}$ : C, 53.26; H, 3.09; N, 4.78\%. IR $\nu_{\max } / \mathrm{cm}^{-1} 2110$ $(\mathrm{C} \equiv \mathrm{C}) ; 1434,1097$ (triphos). ${ }^{1} \mathrm{H}-\mathrm{NMR}$ (400 $\mathrm{MHz}, \mathrm{CDCl}_{3}, 298 \mathrm{~K}$ ) $8.79(3 \mathrm{H}, \mathrm{dd}, J(H-H) 2.1,0.9,6-\mathrm{H}), 8.67$ (3H, ddd, $J(H-H)$ 4.9, 1.8, 0.9, 6'-H), 8.36 (3H, dt, $\left.J(H-H) 8.0,1.1,3^{\prime}-\mathrm{H}\right), 8.32$ (3H, dd, $J(H-H)$ 8.3, 0.9, 3-H), 7.88 (3H, dd, $J(H-H)$ 8.2, 1.8, 4-H), 7.67 $\left(3 \mathrm{H}, \mathrm{td}, J(H-H)=7.7,1.8,4^{\prime}-\mathrm{H}\right), 7.60-7.43\left(33 \mathrm{H}, \mathrm{br} \mathrm{m}, \mathrm{PPh}_{2}+\right.$ $\left.\mathrm{C}_{6} \mathrm{H}_{3} \mathrm{P}_{3}\right), 7.28\left(3 \mathrm{H}\right.$, ddd, $J(H-H)$ 7.8, 4.8, 1.2, $\left.5^{\prime}-\mathrm{H}\right) .{ }^{31} \mathrm{P}\left\{{ }^{1} \mathrm{H}\right\}$ NMR (121.4 MHz, $\left.\mathrm{CDCl}_{3}, 298 \mathrm{~K}\right) 42.9\left(\mathrm{~s}, \mathrm{PPh}_{2}\right) .{ }^{13} \mathrm{C}\left\{{ }^{1} \mathrm{H}\right\}-\mathrm{NMR}$ (100.6 MHz, $\left.\mathrm{CDCl}_{3}, 298 \mathrm{~K}\right)$ 156.0, 153.7 (C2 + C2'), 152.6 (C6), 149.3 (C6'), 140.3 (t, ${ }^{2} J(C-P)$ 14, $\mathrm{CH}-\mathrm{C}_{6} \mathrm{H}_{3} \mathrm{P}_{3}$ ), 140.0 (C4), 137.4 $\left(\mathrm{d},{ }^{2} J(C-P)\right.$ 145, P-Au-C $\left.\equiv \mathrm{C}\right), 137.0\left(\mathrm{C} 4^{\prime}\right), 134.5$ (d, ${ }^{2} J(C-P)$ 14, $\left.\mathrm{C}_{\text {ortho }} \mathrm{Ph}\right), 132.7\left(\mathrm{C}_{\text {para }} \mathrm{Ph}\right), 129.9\left(\mathrm{~d},{ }^{3} J(C-P)\right.$ 11, $\left.\mathrm{C}_{\text {meta }} \mathrm{Ph}\right), 127.7$ (d, ${ }^{1} J(C-P)$ 56, $\mathrm{C}_{i p s o} \mathrm{Ph}$ ), 123.7 (C5'), 122.0 (C5), 121.3 (C3'), 120.4 (C3), $101.0\left(\mathrm{~d},{ }^{3} J(C-P) 25, \mathrm{P}-\mathrm{Au}-\mathrm{C} \equiv C\right) . \mathrm{MS} \operatorname{ESI}(+) \mathrm{m} / \mathrm{z}$ $1759.3\left(15 \%,\left[\mathrm{M}+\mathrm{H}^{+}\right]^{+}\right.$, calc. 1759.3$) ; 1579.2(50 \%,[\mathrm{M}-$ $\left.\mathrm{C}_{12} \mathrm{H}_{7} \mathrm{~N}_{2}\right]^{+}$, calc. 1573.2), $880.1\left(100 \%,\left[\mathrm{M}+2 \mathrm{H}^{+}\right]^{2+}\right.$, calc.: 880.1).

Preparation of $\left[\mathrm{Au}_{4}\left(\mathrm{C} \equiv \mathrm{C}-\mathrm{C}_{10} \mathrm{H}_{7} \mathrm{~N}_{2}\right)_{4}\left(\mu_{4}\right.\right.$-tetraphos $\left.)\right]$ (6). Compound $\mathbf{6}$ was successfully synthesized following analogous procedures to those described for compound 4.

Polymer method. From $(50 \mathrm{mg}, 0.13 \mathrm{mmol})$ of $[\mathrm{Au}(\mathrm{C} \equiv \mathrm{C}-$ $\left.\left.\mathrm{C}_{10} \mathrm{H}_{7} \mathrm{~N}_{2}\right)\right]_{n}$ and (25 mg, $0.03 \mathrm{mmol}$ ) of tetraphos. Yield (55 mg, $77 \%)$.

acac method. From $(100 \mathrm{mg}, 0.05 \mathrm{mmol})$ of $\left[\mathrm{Au}_{4}(\mathrm{acac})_{4}\left(\mu_{4}\right.\right.$-tetraphos)] (3) and (36 mg, $0.20 \mathrm{mmol}$ ) of 5-ethynyl-2,2'-bipyridine and a reaction time of 4 days. Yield ( $59 \mathrm{mg}, 51 \%$ ).
Anal. found: $\mathrm{C}, 52.46 ; \mathrm{H}, 3.34 ; \mathrm{N}, 4.80 ;$ calc. for $\mathrm{C}_{101} \mathrm{H}_{76} \mathrm{Au}_{4} \mathrm{~N}_{8} \mathrm{P}_{4}: \mathrm{C}, 52.43 ; \mathrm{H}, 3.31 ; \mathrm{N}, 4.84 \%$. IR $\nu_{\max } / \mathrm{cm}^{-1}$ $2116(\mathrm{C} \equiv \mathrm{C}) ; 1436,1094$ (tetraphos). ${ }^{1} \mathrm{H}-\mathrm{NMR}(400 \mathrm{MHz}$, $\left.\mathrm{CDCl}_{3}, 298 \mathrm{~K}\right) 8.68\left(4 \mathrm{H}, \mathrm{d}, J(H-H) 4.7,4 \mathrm{H}, 6^{\prime}-\mathrm{H}\right), 8.65(4 \mathrm{H}, \mathrm{d}$, $J(H-H)$ 1.6, 6- $\mathrm{H}), 8.38\left(4 \mathrm{H}, \mathrm{d}, J(H-H) 8.0,3^{\prime}-\mathrm{H}\right), 8.31(4 \mathrm{H}, \mathrm{d}$, $J(H-H) 8.2,3-\mathrm{H}), 7.82\left(4 \mathrm{H}, \mathrm{td}, J(H-H) 7.8,1.9,4^{\prime}-\mathrm{H}\right), 7.73(4 \mathrm{H}$, dd, $J(H-H)$ 8.2, 2.1, 4-H), $7.45\left(40 \mathrm{H}, \mathrm{s} \mathrm{br}, 40 \mathrm{H}, \mathrm{PPh}_{2}\right), 7.29(4 \mathrm{H}$, ddd, $J(\mathrm{H}-\mathrm{H})$ 7.6, 4.8, 1.2, 5'-H), $3.46\left(8 \mathrm{H}, \mathrm{d},{ }^{2} J(H-P)\right.$ 10.7, $\left.\mathrm{CH}_{2}\right)$. ${ }^{31} \mathrm{P}\left\{{ }^{1} \mathrm{H}\right\}$-NMR (121.4 MHz, $\left.\mathrm{CDCl}_{3}, 298 \mathrm{~K}\right) 23.2\left(\mathrm{~s}, \mathrm{PPh}_{2}\right) \cdot{ }^{13} \mathrm{C}$ $\left\{{ }^{1} \mathrm{H}\right\}$-NMR (100.6 MHz, $\left.\mathrm{CDCl}_{3}, 298 \mathrm{~K}\right)$ 156.0, $153.5\left(\mathrm{C} 2+\mathrm{C}^{\prime}\right)$, 152.4 (C6), 149.4 (C6'), 140.0 (C4), 138.6 (d, ${ }^{2} J(C-P)$ 141, P-Au$C \equiv \mathrm{C}$ ), 137.0 (C4'), 133.9, 132.1, 129.8 (br, Ph), 123.7 (C5'), 122.3 (C5), 121.3 (C3'), 120.3 (C3), 101.0 (d, ${ }^{3} J(C-P)$ 27, P-Au$\mathrm{C} \equiv C), 42.7$ ( $\mathrm{C}_{\mathrm{q}}$-tetraphos), 40.7 (dq, $J(\mathrm{C}-\mathrm{P}) 30,7, \mathrm{CH}_{2}$-tetraphos). MS ESI $(+) m / z 2336.3$ (9\%, $\left[\mathrm{M}+\mathrm{Na}^{+}\right]^{+}$, calc. 2336.3); 2134.3 (15\%, $\left[\mathrm{M}-\mathrm{C}_{12} \mathrm{H}_{7} \mathrm{~N}_{2}\right]^{+}$, calc. 2134.3); 1157.7 (40\%, [M + $\left.2 \mathrm{H}^{+}\right]^{2+}$, calc.: 1157.7$)$; $772.1\left(20 \%,\left[\mathrm{M}+3 \mathrm{H}^{+}\right]^{3+}\right.$, calc.: 772.1$)$.

Preparation of $\quad\left[\mathrm{Au}_{4}\left(\mathrm{C} \equiv \mathrm{C}-\mathrm{C}_{10} \mathbf{H}_{7} \mathbf{N}_{2}\right)_{\mathbf{4}}\left(\boldsymbol{\mu}_{\mathbf{4}}\right.\right.$-tpbz) $]$ (7). Compound 7 was obtained as a yellow microcrystalline powder by the polymer method exclusively. From (50 mg, $0.13 \mathrm{mmol}$ ) of $\left[\mathrm{Au}\left(\mathrm{C} \equiv \mathrm{C}-\mathrm{C}_{10} \mathrm{H}_{7} \mathrm{~N}_{2}\right)\right]_{n}$ and $(25 \mathrm{mg}, 0.03 \mathrm{mmol})$ of tpbz. Yield (43 mg, 60\%).

Anal. found: $\mathrm{C}, 52.83 ; \mathrm{H}, 3.03 ; \mathrm{N}, 4.85$; calc. for $\mathrm{C}_{102} \mathrm{H}_{70} \mathrm{Au}_{4} \mathrm{~N}_{8} \mathrm{P}_{4}: \mathrm{C}, 52.82 ; \mathrm{H}, 3.04 ; \mathrm{N}, 4.83 \%$. IR $\nu_{\max } / \mathrm{cm}^{-1}$ 2107 (C三C); 1436, 1101 (tpbz). ${ }^{1} \mathrm{H}-\mathrm{NMR}$ (400 MHz, $\mathrm{CDCl}_{3}$, $298 \mathrm{~K}) 8.81\left(4 \mathrm{H}\right.$, br s, 6-H), $8.65\left(4 \mathrm{H}, \mathrm{d}, J(H-H) 4.9,6^{\prime}-\mathrm{H}\right), 8.35$ $\left(4 \mathrm{H}, \mathrm{d}, J(H-H) 8.0,3^{\prime}-\mathrm{H}\right), 8.26(4 \mathrm{H}, \mathrm{d}, J(H-H) 8.2,3-\mathrm{H}), 7.90$ $(4 \mathrm{H}, \mathrm{dd}, J(H-H) 8.2,2.1,4-\mathrm{H}), 7.77(4 \mathrm{H}, \mathrm{td}, J(H-H) 7.8,1.8$, 4'-H), $7.40\left(10 \mathrm{H}, \mathrm{m}, \mathrm{PPh}_{2}+\mathrm{C}_{6} \mathrm{H}_{2} \mathrm{P}_{4}\right), 7.28-7.19$ (br m, $\mathrm{PPh}_{2}+5^{\prime}-\mathrm{H}$ $\left.+\mathrm{CHCl}_{3}\right) .{ }^{31} \mathrm{P}\left\{{ }^{1} \mathrm{H}\right\}-\mathrm{NMR}\left(121.4 \mathrm{MHz}, \mathrm{CDCl}_{3}, 298 \mathrm{~K}\right) 35.7$ (s, $\left.\mathrm{PPh}_{2}\right) .{ }^{13} \mathrm{C}\left\{{ }^{1} \mathrm{H}\right\}-\mathrm{NMR}\left(100.6 \mathrm{MHz}, \mathrm{CDCl}_{3}, 298 \mathrm{~K}\right)$ 156.1, 153.3 (C2 + C2'), 152.6 (C6), 149.3 (C6'), 144.0 (br, CH- ${ }_{6} \mathrm{H}_{2} \mathrm{P}_{4}$ ), 140.1

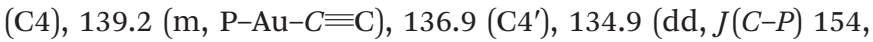
14, CP- $\mathrm{C}_{6} \mathrm{H}_{2} \mathrm{P}_{4}$ ), 134.7, 132.4, 129.6 (Ph), 128.2 (m, $\mathrm{C}_{i p s o} \mathrm{Ph}$ ), 123.5 (C5'), 122.7 (C5), 121.3 (C3'), 120.2 (C3), 102.9 (t, $J(C-P)$ 13, $\mathrm{P}-\mathrm{Au}-\mathrm{C} \equiv C) . \mathrm{MS} \operatorname{ESI}(+) m / z 2139.3\left(5 \%,\left[\mathrm{M}-\mathrm{C}_{12} \mathrm{H}_{7} \mathrm{~N}_{2}\right]^{+}\right.$, calc. 2139.3$) ; 1160.7\left(100 \%,\left[\mathrm{M}+2 \mathrm{H}^{+}\right]^{2+}\right.$, calc.: 1160.7$) ; 773.8$ $\left(6 \%,\left[\mathrm{M}+3 \mathrm{H}^{+}\right]^{3+}\right.$, calc.: 773.8$)$.

Preparation of $\left[\mathrm{Au}_{4}\left(\mathrm{C} \equiv \mathrm{C}-\mathrm{C}_{10} \mathrm{H}_{7} \mathrm{~N}_{2}\right)_{4}\left(\boldsymbol{\mu}_{4}\right.\right.$-dppeda $\left.)\right]$ (8). Compound $\mathbf{8}$ was obtained as a white solid by the polymer method exclusively. From (50 mg, $0.13 \mathrm{mmol})$ of $[\mathrm{Au}(\mathrm{C} \equiv \mathrm{C}-$ $\left.\left.\mathrm{C}_{10} \mathrm{H}_{7} \mathrm{~N}_{2}\right)\right]_{n}$ and (28 $\mathrm{mg}, 0.03 \mathrm{mmol}$ ) of dppeda. Yield (40 mg, $52 \%)$.

Anal. found: $\mathrm{C}, 52.01 ; \mathrm{H}, 3.43 ; \mathrm{N}, 5.95$; calc. for $\mathrm{C}_{102} \mathrm{H}_{80} \mathrm{Au}_{4} \mathrm{~N}_{10} \mathrm{P}_{4}$ : C, 51.96; H, 3.42; N, 5.94\%. IR $\nu_{\max } / \mathrm{cm}^{-1}$ $2106\left(\mathrm{C} \equiv \mathrm{C}\right.$ ); 1435, 1102 (dppeda). ${ }^{1} \mathrm{H}-\mathrm{NMR}$ (400 MHz, $\mathrm{CDCl}_{3}$, 298 K) 8.69-8.67 (8H, br m, 6-H + 6'-H), $8.39(4 \mathrm{H}, \mathrm{d}, J(H-H)$ $\left.8.0,3^{\prime}-\mathrm{H}\right), 8.27(4 \mathrm{H}, \mathrm{d}, J(H-H) 8.3,3-\mathrm{H}), 7.81(4 \mathrm{H}, \mathrm{td}, J(H-H)$ $\left.7.8,1.8,4^{\prime}-\mathrm{H}\right), 7.77-7.73\left(16 \mathrm{H}, \mathrm{m}, \mathrm{PPh}_{2}\right), 7.68(4 \mathrm{H}, \mathrm{dd}, J(H-H)$ 8.2, 2.2, 4-H), 7.37-7.35 (24H, m, $\left.\mathrm{PPh}_{2}\right), 7.29(4 \mathrm{H}$, ddd, $4 \mathrm{H}$, $\left.J(H-H) 7.5,4.8,1.2,5^{\prime}-\mathrm{H}\right), 4.07\left(8 \mathrm{H}, \mathrm{s}, \mathrm{CH}_{2} \mathrm{P}\right), 2.76(4 \mathrm{H}, \mathrm{s}$, $\left.\mathrm{CH}_{2} \mathrm{~N}\right) .{ }^{31} \mathrm{P}\left\{{ }^{1} \mathrm{H}\right\}-\mathrm{NMR}\left(121.4 \mathrm{MHz}, \mathrm{CDCl}_{3}, 298 \mathrm{~K}\right) 27.1\left(\mathrm{~s}, \mathrm{PPh}_{2}\right)$. ${ }^{13} \mathrm{C}\left\{{ }^{1} \mathrm{H}\right\}-\mathrm{NMR}\left(100.6 \mathrm{MHz}, \mathrm{CDCl}_{3}, 298 \mathrm{~K}\right)$ 156.0, $153.5(\mathrm{C} 2+$ C2'), 152.5 (C6), 149.4 (C6'), 139.9 (C4), 139.1 (d, ${ }^{2} J(C-P)$ 13, $\left.\mathrm{C}_{\text {ortho }} \mathrm{Ph}\right), 137.0\left(\mathrm{C}^{\prime}\right), 134.1$ (d, $\left.{ }^{2} J(C-P) 13, \mathrm{C}_{\text {ortho }} \mathrm{Ph}\right), 132.1$ (C $\mathrm{C}_{\text {para }} \mathrm{Ph}$ ), 123.7 (C5'), 122.3 (C5), 121.3 (C3'), 120.3 (C3), 56.6 
(br, $\left.\mathrm{NCH}_{2} \mathrm{P}\right), 53.7\left(\mathrm{CH}_{2} \mathrm{~N}\right)(\mathrm{AuC} \equiv \mathrm{C}$ not observed). HRMS ESI(+) $m / z 2178.357$ (5\%, [M - $\left.\mathrm{C}_{12} \mathrm{H}_{7} \mathrm{~N}_{2}\right]^{+}$, calc. 2178.360); 1801.327 (15\%, $\left[\mathrm{M}-\mathrm{C}_{12} \mathrm{H}_{7} \mathrm{~N}_{2}-\mathrm{AuC}_{12} \mathrm{H}_{7} \mathrm{~N}_{2}\right]^{2+}$, calc.: 1801.329).

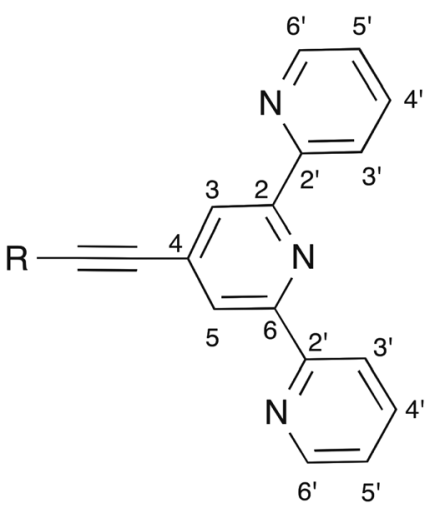

Numbering Scheme

Preparation of $\left[\mathrm{Au}_{3}\left(\mathrm{C} \equiv \mathrm{C}-\mathrm{C}_{15} \mathbf{H}_{10} \mathbf{N}_{3}\right)_{3}\left(\boldsymbol{\mu}_{3}\right.\right.$-triphos) $]$ (9)

Polymer method. From $(60 \mathrm{mg}, 0.13 \mathrm{mmol})$ of $[\mathrm{Au}(\mathrm{C} \equiv \mathrm{C}-$ $\left.\left.\mathrm{C}_{15} \mathrm{H}_{10} \mathrm{~N}_{3}\right)\right]_{n}$ and $(25 \mathrm{mg}, 0.04 \mathrm{mmol}$ ) of triphos. Yield (41 mg, $46 \%)$.

acac method. From (76 mg, $0.05 \mathrm{mmol})$ of $\left[\mathrm{Au}_{3}(\mathrm{acac})_{3}\left(\mu_{3^{-}}\right.\right.$ triphos)] (1) and (39 mg, $0.15 \mathrm{mmol})$ of $4^{\prime}$-ethynyl-2,2':6',2"-terpyridine and a reaction time of 2 days. Yield ( $36 \mathrm{mg}, 36 \%$ ).

Anal. found: $\mathrm{C}, 55.63 ; \mathrm{H}, 3.53 ; \mathrm{N}, 6.32$; calc. for $\mathrm{C}_{92} \mathrm{H}_{69} \mathrm{Au}_{3} \mathrm{~N}_{9} \mathrm{P}_{3}$ : C, 55.68; H, 3.50; N, 6.35\%. IR $\nu_{\max } / \mathrm{cm}^{-1} 2119$ $(\mathrm{C} \equiv \mathrm{C}) ; 1486,1435,1097$ (triphos). ${ }^{1} \mathrm{H}-\mathrm{NMR}$ (400 $\mathrm{MHz}, \mathrm{CDCl}_{3}$, $298 \mathrm{~K}) 8.70\left(6 \mathrm{H}, \mathrm{d}, J(H-H) 4.8,6^{\prime}-\mathrm{H}\right), 8.59(6 \mathrm{H}, \mathrm{d}, J(H-H)$ 8.1, 3'-H), $8.52(6 \mathrm{H}, \mathrm{s}, 3-\mathrm{H}+5-\mathrm{H}), 7.96-7.91\left(12 \mathrm{H}, \mathrm{m}, \mathrm{PPh}_{2}\right), 7.84$ $\left(6 \mathrm{H}, \mathrm{td}, J(H-H) 8.1,1.8,4^{\prime}-\mathrm{H}\right), 7.51-7.45\left(18 \mathrm{H}\right.$, br $\left.\mathrm{m}, \mathrm{PPh}_{2}\right)$, 7.31 (6H, m, 5'-H), $3.46\left(6 \mathrm{H}, \mathrm{d},{ }^{2} J(H-P) 10.9, \mathrm{CH}_{2}\right), 0.92(3 \mathrm{H}, \mathrm{s}$, $\left.\mathrm{CH}_{3}\right) .{ }^{31} \mathrm{P}\left\{{ }^{1} \mathrm{H}\right\}-\mathrm{NMR}\left(161.9 \mathrm{MHz}, \mathrm{CDCl}_{3}, 298 \mathrm{~K}\right) 25.3\left(\mathrm{~s}, \mathrm{PPh}_{2}\right)$. ${ }^{13} \mathrm{C}\left\{{ }^{1} \mathrm{H}\right\}$-NMR (125.7 MHz, $\left.\mathrm{CDCl}_{3}, 298 \mathrm{~K}\right)$ 156.3, 155.4 (C2 + C2' + C6), 149.3 (C6'), 139.8 (d, ${ }^{2} J(C-P)$ 139, $\left.\mathrm{P}-\mathrm{Au}-C \equiv \mathrm{C}\right), 136.8$ (C4'), 135.2 (C4), 134.0 (d, ${ }^{2} J(C-P)$ 14, $\left.\mathrm{C}_{\text {ortho }} \mathrm{Ph}\right), 132.2\left(\mathrm{C}_{\text {para }} \mathrm{Ph}\right)$, $130.9\left(\mathrm{~d},{ }^{1} J(C-P)\right.$ 55, $\left.\mathrm{C}_{\text {ipso }} \mathrm{Ph}\right), 129.8\left(\mathrm{~d},{ }^{3} J(C-P)\right.$ 11.2, $\left.\mathrm{C}_{\text {meta }} \mathrm{Ph}\right)$, 124.1 (C5'), 123.8 (C3 + C5), 121.2 (C3'), 102.6 (d, ${ }^{3} J(C-P)$ 24, $\mathrm{P}-\mathrm{Au}-\mathrm{C} \equiv C), 42.7\left(\mathrm{~d},{ }^{1} J(C-P) 27.9, \mathrm{CH}_{2}\right), 38.9$ ( $\mathrm{C}_{\mathrm{q}}$-triphos), 31.0 $\left(\mathrm{CH}_{3}\right)$. HRMS ESI(+) $\mathrm{m} / \mathrm{z} 1985.399$ (45\%, [M $\left.+\mathrm{H}^{+}\right]^{+}$, calc. 1985.399); 1727.300 (15\%, [M - $\left.\mathrm{C}_{17} \mathrm{H}_{10} \mathrm{~N}_{3}\right]^{+}$, calc. 1727.301); 993.203 (15\%, $\left[\mathrm{M}+2 \mathrm{H}^{+}\right]^{2+}$, calc.: 993.204).

Preparation of $\left[\mathrm{Au}_{3}\left(\mathrm{C} \equiv \mathrm{C}-\mathrm{C}_{\mathbf{1 5}} \mathbf{H}_{10} \mathbf{N}_{3}\right)_{3}\left(\boldsymbol{\mu}_{3}\right.\right.$-triphosph $\left.)\right]$ (10)

Polymer method. From (60 mg, $0.13 \mathrm{mmol})$ of $[\mathrm{Au}(\mathrm{C} \equiv \mathrm{C}-$ $\left.\left.\mathrm{C}_{15} \mathrm{H}_{10} \mathrm{~N}_{3}\right)\right]_{n}$ and (25 mg, $0.04 \mathrm{mmol}$ ) of triphosph. Yield (31 mg, 42\%).

acac method. From $(76 \mathrm{mg}, 0.05 \mathrm{mmol})$ of $\left[\mathrm{Au}_{3}(\mathrm{acac})_{3}\left(\mu_{3}\right.\right.$-triphosph)] (2) and (39 mg, $0.15 \mathrm{mmol}$ ) of 4'-ethynyl-2,2':6',2"-terpyridine and a reaction time of 2 days. Yield ( $24 \mathrm{mg}, 24 \%$ ).

Anal. found: $\mathrm{C}, 56.23 ; \mathrm{H}, 3.23 ; \mathrm{N}, 6.32$; calc. for $\mathrm{C}_{93} \mathrm{H}_{63} \mathrm{Au}_{3} \mathrm{~N}_{9} \mathrm{P}_{3}$ : C, 56.12; H, 3.19; N, 6.33\%. IR $\nu_{\text {max }} / \mathrm{cm}^{-1} 2119$ $(\mathrm{C} \equiv \mathrm{C}) ; 1435,1100$ (triphos). ${ }^{1} \mathrm{H}-\mathrm{NMR}\left(300 \mathrm{MHz}, \mathrm{CDCl}_{3}, 298 \mathrm{~K}\right)$ 8.69 (6H, dq, $\left.J(H-H) 4.8,0.9 \mathrm{~Hz}, 6 \mathrm{H}, 6^{\prime}-\mathrm{H}\right), 8.58(6 \mathrm{H}, \mathrm{dt}, J(H-H)$ 6.0, 0.9, 3'- $-\mathrm{H}), 8.55(6 \mathrm{H}, \mathrm{s}, 3-\mathrm{H}+5-\mathrm{H}), 7.83(6 \mathrm{H}, \mathrm{td}, J(H-H) 7.5$, 1.8, 4'- $-\mathrm{H}), 7.70-7.44\left(33 \mathrm{H}, \mathrm{br}, \mathrm{PPh}_{2}+\mathrm{P}-\mathrm{C}_{6} \mathrm{H}_{3}-\mathrm{P}\right), 7.30(6 \mathrm{H}$, ddd, $\left.J(H-H) 7.5,4.8,1.8,6 \mathrm{H}, 55^{\prime}-\mathrm{H}\right) .{ }^{31} \mathrm{P}\left\{{ }^{1} \mathrm{H}\right\}-\mathrm{NMR}(121.4 \mathrm{MHz}$,
$\left.\mathrm{CDCl}_{3}, 298 \mathrm{~K}\right) 42.9\left(\mathrm{~s}, \mathrm{PPh}_{2}\right) .{ }^{13} \mathrm{C}\left\{{ }^{1} \mathrm{H}\right\}-\mathrm{NMR}\left(125.7 \mathrm{MHz}, \mathrm{CDCl}_{3}\right.$, 298 K) 156.4, 155.5 (C2 + C2' + C6), 149.3 (C6'), 140.7 (br, P$\mathrm{Au}-C \equiv \mathrm{C}), 136.8$ (C4'), 135.1 (C4), 134.5 (d, ${ }^{2} J(C-P)$ 14, $\left.\mathrm{C}_{\text {ortho }} \mathrm{Ph}\right), 132.7$ (s, $\left.\mathrm{C}_{\text {para }} \mathrm{Ph}\right), 130.0$ (d, $\left.{ }^{3} J(C-P) 12, \mathrm{C}_{\text {meta }} \mathrm{Ph}\right)$, 127.8 (d, ${ }^{1} J(C-P)$ 57, $\left.\mathrm{C}_{i p s o} \mathrm{Ph}\right), 124.1$ (C5'), 123.8 (C3 + C5), 121.2 (C3'), 102.3 (br, $\mathrm{P}-\mathrm{Au}-\mathrm{C} \equiv C)$ ). HRMS $\operatorname{ESI}(+) \mathrm{m} / \mathrm{z}=$ $1991.354\left(<1 \%,\left[\mathrm{M}+\mathrm{H}^{+}\right]^{+}\right.$, calc. 1991.353); $996.191(<1 \%,[\mathrm{M}+$ $\left.2 \mathrm{H}^{+}\right]^{2+}$, calc. 996.180); $258.103\left(100 \%,\left[\mathrm{C}_{17} \mathrm{H}_{11} \mathrm{~N}_{3}+\mathrm{H}^{+}\right]^{+}\right.$, calc. 258.103).

Preparation of $\left[\mathrm{Au}_{\mathbf{4}}\left(\mathrm{C} \equiv \mathrm{C}-\mathrm{C}_{\mathbf{1 5}} \mathbf{H}_{\mathbf{1 0}} \mathbf{N}_{\mathbf{3}}\right)_{\mathbf{4}}\left(\boldsymbol{\mu}_{\mathbf{4}}\right.\right.$-tetraphos $\left.)\right]$ (11)

Polymer method. From $(60 \mathrm{mg}, 0.13 \mathrm{mmol})$ of $[\mathrm{Au}(\mathrm{C} \equiv \mathrm{C}-$ $\left.\left.\mathrm{C}_{15} \mathrm{H}_{10} \mathrm{~N}_{3}\right)\right]_{n}$ and $(28 \mathrm{mg}, 0.03 \mathrm{mmol})$ of tetraphos. Yield (40 mg, 44\%).

acac method. From $(100 \mathrm{mg}, 0.05 \mathrm{mmol})$ of $\left[\mathrm{Au}_{4}(\mathrm{acac})_{4}\left(\mu_{4}\right.\right.$-tetraphos)] (2) and (51 mg, $0.2 \mathrm{mmol}$ ) of $4^{\prime}$-ethynyl-2,2':6',2"-terpyridine and a reaction time 3 days. Yield (40 mg, 30\%).

Anal. found: $\mathrm{C}, 55.23 ; \mathrm{H}, 3.33 ; \mathrm{N}, 6.42$; calc. for $\mathrm{C}_{121} \mathrm{H}_{88} \mathrm{Au}_{4} \mathrm{~N}_{12} \mathrm{P}_{4}$ : C, 55.43; H, 3.38; N, 6.41\%. IR $\nu_{\max } / \mathrm{cm}^{-1}$ $2117(\mathrm{C} \equiv \mathrm{C}) ; 1440,1100$ (tetraphos). ${ }^{1} \mathrm{H}-\mathrm{NMR}(500 \mathrm{MHz}$, $\left.\mathrm{CDCl}_{3}, 298 \mathrm{~K}\right) 8.73\left(8 \mathrm{H}, \mathrm{ddd}, J(H-H) 4.7,1.8,0.9,66^{\prime}-\mathrm{H}\right), 8.60$ $\left(8 \mathrm{H}, \mathrm{dt}, J(H-H) 7.9,1.1,3^{\prime}-\mathrm{H}\right), 8.44(8 \mathrm{H}, \mathrm{s}, 3-\mathrm{H}+5-\mathrm{H}), 8.30-7.00$ (overlapped with terpy signals, very br, $\mathrm{P} P h_{2}$ ), 7.85 (overlapped with $\mathrm{PPh}$, ddd, $J(H-H)$ 8.8, 7.5, 1.8, 4'-H), 7.33 (overlapped with $\mathrm{PPh}_{2}$, ddd, $J(H-H)$ 7.5, 4.8, 1.2, 5'-H), $3.53\left(8 \mathrm{H}, \mathrm{br}, \mathrm{CH}_{2}\right) .{ }^{31} \mathrm{P}$ $\left\{{ }^{1} \mathrm{H}\right\}$-NMR (121.4 MHz, $\left.\mathrm{CDCl}_{3}, 298 \mathrm{~K}\right) 22.9\left(\mathrm{~s}, \mathrm{PPh}_{2}\right) .{ }^{13} \mathrm{C}\left\{{ }^{1} \mathrm{H}\right\}$ NMR (125.7 MHz, $\left.\mathrm{CDCl}_{3}, 298 \mathrm{~K}\right)$ 156.4, 155.3 (C2 + C2' + C6), 149.3 (C6'), 140.1 (d, $\left.{ }^{2} J(C-P) 141, \mathrm{P}-\mathrm{Au}-C \equiv \mathrm{C}\right), 136.8\left(\mathrm{C}^{\prime}\right), 135.4$ (C4), 133.8, 132.4, 130.0 (br, Ph), 124.2 (C3 + C5), 123.8 (C5'), $121.2\left(\mathrm{C}^{\prime}\right), 102.2\left(\mathrm{~d},{ }^{3} J(C-P) 26, \mathrm{P}-\mathrm{Au}-\mathrm{C} \equiv C\right), 42.8\left(C\left(\mathrm{CH}_{2}\right)_{4}\right)$, $40.7\left(\mathrm{~d},{ }^{1} J(C-P) 30, \mathrm{C}\left(\mathrm{CH}_{2}\right)_{4}\right)$. HRMS ESI $(+) \mathrm{m} / z=2622.491(<1 \%$, $\left[\mathrm{M}+\mathrm{H}^{+}\right]^{+}$, calc. 2622.498); $2169.438\left(4 \%,\left[\mathrm{M}-\mathrm{C}_{17} \mathrm{H}_{10} \mathrm{~N}_{3} \mathrm{Au}+\right.\right.$ $\left.\mathrm{H}^{+}\right]^{+}$, calc. 2169.443$) ; 1311.749\left(8 \%,\left[\mathrm{M}+2 \mathrm{H}^{+}\right]^{2+}\right.$, calc. 1311.752); $258.103\left(100 \%,\left[\mathrm{C}_{17} \mathrm{H}_{11} \mathrm{~N}_{3}+\mathrm{H}^{+}\right]^{+}\right.$, calc. 258.103).

Preparation of $\left[\mathrm{Au}_{4}\left(\mathrm{C} \equiv \mathrm{C}-\mathrm{C}_{15} \mathrm{H}_{10} \mathbf{N}_{3}\right)_{4}\left(\mu_{4}\right.\right.$-tpbz) $] \quad$ (12). Compound 12 was obtained as an orange microcrystalline powder by the polymer method exclusively. From $(60 \mathrm{mg}$, $0.13 \mathrm{mmol})$ of $\left[\mathrm{Au}\left(\mathrm{C} \equiv \mathrm{C}-\mathrm{C}_{15} \mathrm{H}_{10} \mathrm{~N}_{3}\right)\right]_{n}$ and $(28 \mathrm{mg}, 0.03 \mathrm{mmol})$ of tpbz. Yield (50 mg, 62\%).

Anal. found: $\mathrm{C}, 55.83 ; \mathrm{H}, 3.13 ; \mathrm{N}, 4.37$; calc. for $\mathrm{C}_{122} \mathrm{H}_{82} \mathrm{Au}_{4} \mathrm{~N}_{12} \mathrm{P}_{4}: \mathrm{C}, 55.76 ; \mathrm{H}, 3.15 ; \mathrm{N}, 6.40 \%$. IR $\nu_{\max } / \mathrm{cm}^{-1}$ $2113 \nu(\mathrm{C} \equiv \mathrm{C})$; 1505, 1435, 1097 (tpbz). ${ }^{1} \mathrm{H}-\mathrm{NMR}(500 \mathrm{MHz}$, $\left.\mathrm{CDCl}_{3}, 298 \mathrm{~K}\right) 8.54\left(8 \mathrm{H}, \mathrm{d}, J(H-H) 4.5,66^{\prime}-\mathrm{H}\right), 8.49(8 \mathrm{H}, \mathrm{s}, 3-\mathrm{H}+$ 5-H), 8.40 (8H, d, $\left.J(H-H) 8.1,3^{\prime}-\mathrm{H}\right), 7.71(8 \mathrm{H}, \mathrm{td}, J(H-H) 7.8$, 1.8, 4'-H), 7.43-7.22 (m, $\mathrm{PPh}_{2}+\mathrm{P}-\mathrm{C}_{6} \mathrm{H}_{2}-\mathrm{P}+$ residual proton of $\mathrm{CDCl}_{3}$ ), $7.18\left(8 \mathrm{H}, \mathrm{m}, 5^{\prime}-\mathrm{H}\right) .{ }^{31} \mathrm{P}\left\{{ }^{1} \mathrm{H}\right\}-\mathrm{NMR}\left(121.4 \mathrm{MHz}, \mathrm{CDCl}_{3}\right.$, $298 \mathrm{~K}) 35.5\left(\mathrm{~s}, \mathrm{PPh}_{2}\right) \cdot{ }^{13} \mathrm{C}\left\{{ }^{1} \mathrm{H}\right\}-\mathrm{NMR}\left(125.7 \mathrm{MHz}, \mathrm{CDCl}_{3}, 298 \mathrm{~K}\right)$ 156.5, 155.1 (C2 + C2' + C6), $149.1\left(\mathrm{C}^{\prime}\right), 144.1$ (br, $\mathrm{CH}-$

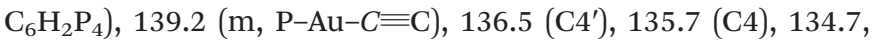
132.4, $129.6(\mathrm{Ph}), 128.4\left(\mathrm{~m}, \mathrm{C}_{i p s o} \mathrm{Ph}\right), 124.3$ (C3 + C5), 123.4 (C5'), 121.1 (s, C3'), 104.0 (m, P-Au-C $\equiv C$ ). HRMS ESI $(+) m / z$ $2628.445\left(3 \%,\left[\mathrm{M}+\mathrm{H}^{+}\right]^{+}\right.$, calc. 2628.450); 2371.338 (4\%, $[\mathrm{M}-$ $\left.\mathrm{C}_{17} \mathrm{H}_{10} \mathrm{~N}_{3}\right]^{+}$, calc. 2371.355$) ; 1314.728\left(100 \%\left[\mathrm{M}+2 \mathrm{H}^{+}\right]^{2+}\right.$, calc. 1314.729); 876.817 (30\%, $\left[\mathrm{M}+3 \mathrm{H}^{+}\right]^{3+}$, calc.: 876.822$) ; 657.870$ $\left(20 \%,\left[\mathrm{M}+4 \mathrm{H}^{+}\right]^{4+}\right.$, calc. 657.869$)$.

Preparation of $\left[\mathrm{Au}_{4}\left(\mathrm{C} \equiv \mathrm{C}-\mathrm{C}_{15} \mathrm{H}_{10} \mathbf{N}_{3}\right)_{4}\left(\boldsymbol{\mu}_{4}\right.\right.$-dppeda $\left.)\right]$ (13). Compound $\mathbf{1 3}$ was obtained as a white solid by the polymer 
method exclusively. From $(60 \mathrm{mg}, 0.13 \mathrm{mmol})$ of $[\mathrm{Au}(\mathrm{C} \equiv \mathrm{C}-$ $\left.\left.\mathrm{C}_{15} \mathrm{H}_{10} \mathrm{~N}_{3}\right)\right]_{n}$ and (28 mg, $0.03 \mathrm{mmol}$ ) of dppeda. Yield (40 mg, $46 \%)$.

Anal. found: $\mathrm{C}, 54.63 ; \mathrm{H}, 3.42 ; \mathrm{N}, 7.32$; calc. for $\mathrm{C}_{122} \mathrm{H}_{92} \mathrm{Au}_{4} \mathrm{~N}_{14} \mathrm{P}_{4}: \mathrm{C}, 54.97 ; \mathrm{H}, 3.48 ; \mathrm{N}, 7.36 \%$. IR $\nu_{\max } / \mathrm{cm}^{-1}$ $2116(\mathrm{C} \equiv \mathrm{C}) ; 1504,1435,1100$ (dppeda). ${ }^{1} \mathrm{H}-\mathrm{NMR}(300 \mathrm{MHz}$, $\left.\mathrm{CDCl}_{3}, 298 \mathrm{~K}\right) 8.70\left(8 \mathrm{H}, \mathrm{d}, J(H-H) 4.2,6^{\prime}-\mathrm{H}\right), 8.59(8 \mathrm{H}, \mathrm{d}, J(H-$ $\left.H)=8.0 \mathrm{~Hz}, 3^{\prime}-\mathrm{H}\right), 8.47(8 \mathrm{H}, \mathrm{s}, 3-\mathrm{H}+5-\mathrm{H}), 7.85-7.74(24 \mathrm{H}, \mathrm{m}$, $\left.4^{\prime}-\mathrm{H}+\mathrm{PPh}_{2}\right), 7.41-7.30\left(32 \mathrm{H}, \mathrm{m}, 5^{\prime}-\mathrm{H}+\mathrm{PPh}_{2}\right), 4.12(8 \mathrm{H}, \mathrm{br}$, $\left.\mathrm{CH}_{2} \mathrm{P}\right), 2.73\left(4 \mathrm{H}, \mathrm{br}, \mathrm{CH}_{2} \mathrm{~N}\right) .{ }^{31} \mathrm{P}\left\{{ }^{1} \mathrm{H}\right\}-\mathrm{NMR}$ (121.4 $\mathrm{MHz} \mathrm{CDCl}_{3}$, $298 \mathrm{~K}) 27.2\left(\mathrm{~s}, \mathrm{PPh}_{2}\right) \cdot{ }^{13} \mathrm{C}\left\{{ }^{1} \mathrm{H}\right\}-\mathrm{NMR}\left(125.7 \mathrm{MHz}, \mathrm{CDCl}_{3}, 298 \mathrm{~K}\right)$ 156.3, 155.4 (C2 + C2' + C6), $149.3\left(\mathrm{C}^{\prime}\right), 140.0\left(\mathrm{~d},{ }^{2} J(C-P)\right.$ 139, $\mathrm{P}-\mathrm{Au}-C \equiv \mathrm{C}), 136.8$ (C4'), 135.3 (C4), 134.1 (d, ${ }^{2} J(C-P)$ 13, $\left.\mathrm{C}_{\text {ortho }} \mathrm{Ph}\right), 132.1\left(\mathrm{C}_{\text {para }} \mathrm{Ph}\right), 129.7$ (d, ${ }^{3} J(C-P)$ 11, $\left.\mathrm{C}_{\text {meta }} \mathrm{Ph}\right), 129.3$ (s, $\mathrm{C}_{\text {ipso }} \mathrm{Ph}$ ), 124.0 (C5'), 123.8 (C3 + C5), 121.2 (C3'), 102.9 (d, $\left.{ }^{3} J(C-P) 25, \mathrm{P}-\mathrm{Au}-\mathrm{C} \equiv C\right), 56.8$ (br, $\mathrm{NCH}_{2} \mathrm{P}$ ), 53.5 (br, $\mathrm{CH}_{2} \mathrm{~N}$ ). HRMS ESI $(+) m / z 2409.437\left(40 \%,\left[\mathrm{M}-\mathrm{C}_{17} \mathrm{H}_{10} \mathrm{~N}_{3}\right]^{+}\right.$, calc. 2409.439); 1205.221 (100\%, $\left[\mathrm{M}-\mathrm{C}_{17} \mathrm{H}_{10} \mathrm{~N}_{3}+\mathrm{H}^{+}\right]^{2+}$, calc. 1205.224); 803.818 (90\%, $\left[\mathrm{M}-\mathrm{C}_{17} \mathrm{H}_{10} \mathrm{~N}_{3}+2 \mathrm{H}^{+}\right]^{3+}$, calc. 803.818); 603.115 (8\%, $\left[\mathrm{M}-\mathrm{C}_{17} \mathrm{H}_{10} \mathrm{~N}_{3}+3 \mathrm{H}^{+}\right]^{4+}$, calc. 603.116).

\section{Conflicts of interest}

There are no conflicts to declare.

\section{Acknowledgements}

Financial support for this work was provided by the Ministerio de Economía y Competitividad (MINECO/FEDER) of Spain (Projects CTQ2015-65040-P, CTQ2015-65707-C2-1-P, CTQ201676120-P and CTQ2013-44625-R) AEI/FEDER, UE, and the Universidad de Alcalá (CCG2014/EXP-022). The authors are also grateful to the Associated Laboratory for Sustainable Chemistry-Clean Processes and Technologies-LAQV, which is financed by national funds from FCT/MEC (UID/QUI/50006/ 2013) and co-financed by the ERDF under the PT2020 Partnership Agreement (POCI-01-0145-FEDER-007265) and to the Academy of Finland (Project numbers RP: 298817, KR: 263256, 265328 and 292746) and the University of Jyväskylä for financial support.

\section{References}

1 C. Jobbagy and A. Deak, Eur. J. Inorg. Chem., 2014, 44344449.

2 J. F. Zhang, Y. Zhou, J. Yoon and J. S. Kim, Chem. Soc. Rev., 2011, 40, 3416-3429.

3 Q. A. Zhao, F. Y. Li and C. H. Huang, Chem. Soc. Rev., 2010, 39, 3007-3030.

4 M. Humphrey, Gold Bull., 2000, 33, 97-102.

5 S. Goswami, G. Wicks, A. Rebane and K. Schanze, Dalton Trans., 2014, 43, 17721-17728.
6 G. Liu, C. Quintana, G. Wang, M. S. Kodikara, J. Du, R. Stranger, C. Zhang, M. P. Cifuentes and M. G. Humphrey, Aust. J. Chem., 2017, 70, 79-89.

7 C. Halliday and J. Lynam, Dalton Trans., 2016, 45, 1261112626.

8 A. Hashmi, Acc. Chem. Res., 2014, 47, 864-876.

9 T. Boorman and I. Larrosa, Chem. Soc. Rev., 2011, 40, 1910-1925.

10 M. Rudolph and A. Hashmi, Chem. Soc. Rev., 2012, 41, 2448-2462.

11 E. Langdon-Jones and S. Pope, Chem. Commun., 2014, 50, 10343-10354.

12 J. C. Lima and L. Rodriguez, Anti-Cancer Agents Med. Chem., 2011, 11, 921-928.

13 C. M. Che and R. W. Y. Sun, Chem. Commun., 2011, 47, 9554-9560.

14 E. Langdon-Jones, D. Lloyd, A. Hayes, S. Wainwright, H. Mottram, S. Coles, P. Horton and S. Pope, Inorg. Chem., 2015, 54, 6606-6615.

15 V. W. W. Yam and K. K. W. Lo, Chem. Soc. Rev., 1999, 28, 323-334.

16 V. W. W. Yam and E. C. C. Cheng, Chem. Soc. Rev., 2008, 37, 1806-1813.

17 V. Yam, V. Au and S. Leung, Chem. Rev., 2015, 115, 75897728.

18 V. W. W. Yam and K. M. C. Wong, Chem. Commun., 2011, 47, 11579-11592.

19 E. R. T. Tiekink and J. G. Kang, Coord. Chem. Rev., 2009, 253, 1627-1648.

20 H. Schmidbaur and A. Schier, Chem. Soc. Rev., 2012, 41, 370-412.

21 H. Schmidbaur and A. Schier, Chem. Soc. Rev., 2008, 37, 1931-1951.

22 R. J. Puddephatt, Chem. Soc. Rev., 2008, 37, 2012-2027.

23 M. J. Katz, K. Sakai and D. B. Leznoff, Chem. Soc. Rev., 2008, 37, 1884-1895.

24 H. Schmidbaur, Gold Bull., 2000, 33, 3-10.

25 J. C. Lima and L. Rodriguez, Chem. Soc. Rev., 2011, 40, 5442-5456.

26 L. Rodriguez and J. C. Lima, Global J. Inorg. Chem., 2011, 2, 39-64.

27 X. L. Li, M. Tan, K. J. Zhang, B. Yang, J. Chen and Y. B. Ai, Inorg. Chem., 2012, 51, 109-118.

28 I. O. Koshevoy, A. J. Karttunen, S. P. Tunik, M. Haukka, S. I. Selivanov, A. S. Melnikov, P. Y. Serdobintsev and T. A. Pakkanen, Organometallics, 2009, 28, 1369-1376.

29 I. O. Koshevoy, L. Koskinen, M. Haukka, S. P. Tunik, P. Y. Serdobintsev, A. S. Melnikov and T. A. Pakkanen, Angew. Chem., Int. Ed., 2008, 47, 3942-3945.

30 I. O. Koshevoy, A. J. Karttunen, S. P. Tunik, M. Haukka, S. I. Selivanov, A. S. MeInikov, P. Y. Serdobintsev, M. A. Khodorkovskiy and T. A. Pakkanen, Inorg. Chem., 2008, 47, 9478-9488.

31 S. K. Yip, E. C. C. Cheng, L. H. Yuan, N. Y. Zhu and V. W. W. Yam, Angew. Chem., Int. Ed., 2004, 43, 49544957. 
32 A. Moro, B. Rome, E. Aguilo, J. Arcau, R. Puttreddy, K. Rissanen, J. Lima and L. Rodriguez, Org. Biomol. Chem., 2015, 13, 2026-2033.

33 I. O. Koshevoy, C. L. Lin, C. C. Hsieh, A. J. Karttunen, M. Haukka, T. A. Pakkanen and P. T. Chou, Dalton Trans., 2012, 41, 937-945.

34 I. Kondrasenko, K. Chung, Y. Chen, J. Koivistoinen, E. Grachova, A. Karttunen, P. Chou and I. Koshevoy, J. Phys. Chem. C, 2016, 120, 12196-12206.

35 J. Camara, O. Crespo, M. Gimeno, I. Koshevoy, A. Laguna, I. Ospino, E. Smirnova and S. Tunik, Dalton Trans., 2012, 41, 13891-13898.

36 J. R. Shakirova, E. V. Grachova, V. V. Gurzhiy, I. O. Koshevoy, A. S. Melnikov, O. V. Sizova, S. P. Tunik and A. Laguna, Dalton Trans., 2012, 41, 2941-2949.

37 V. W. W. Yam, K. K. W. Lo and K. M. C. Wong, J. Organomet. Chem., 1999, 578, 3-30.

38 M. Ferrer, L. Rodriguez, O. Rossell, F. Pina, J. C. Lima, M. F. Bardia and X. Solans, J. Organomet. Chem., 2003, 678, 82-89.

39 M. Ferrer, A. Gutierrez, L. Rodriguez, O. Rossell, J. C. Lima, M. Font-Bardia and X. Solans, Eur. J. Inorg. Chem., 2008, 2899-2909.

40 Z. N. Chen, Y. Fan and J. Ni, Dalton Trans., 2008, 573-581.

41 J. Vicente, J. Gil-Rubio, N. Barquero, P. G. Jones and D. Bautista, Organometallics, 2008, 27, 646-659.

42 H. B. Xu, L. Y. Zhang, J. Ni, H. Y. Chao and Z. N. Chen, Inorg. Chem., 2008, 47, 10744-10752.

43 R. Packheiser, P. Ecorchard, T. Ruffer, B. Walforta and H. Lang, Eur. J. Inorg. Chem., 2008, 4152-4165.

44 R. Packheiser, P. Ecorchard, T. Rueffer and H. Lang, Chem. - Eur. J., 2008, 14, 4948-4960.

45 R. Packheiser, A. Jakob, P. Ecorchard, B. Walfort and H. Lang, Organometallics, 2008, 27, 1214-1226.

46 R. Packheiser and H. Lang, Inorg. Chim. Acta, 2011, 366, 177-183.

47 X. L. Li, K. J. Zhang, J. J. Li, X. X. Cheng and Z. N. Chen, Eur. J. Inorg. Chem., 2010, 3449-3457.

48 E. C. Constable, C. E. Housecroft, M. Neuburger, S. Schaffner and E. J. Shardlow, Dalton Trans., 2007, 26312633.

49 E. C. Constable, C. E. Housecroft, M. Neuburger, S. Schaffner and E. J. Shardlow, Polyhedron, 2008, 27, 6570.

50 E. C. Constable, C. E. Housecroft, M. K. Kocik and J. A. Zampese, Polyhedron, 2011, 30, 2704-2710.

51 J. Vicente, J. Gil-Rubio, N. Barquero, V. Camara and N. Masciocchi, Chem. Commun., 2010, 46, 1053-1055.

52 V. Camara, N. Masciocchi, J. Gil-Rubio and J. Vicente, Chem. - Eur. J., 2014, 20, 1389-1402.

53 V. Camara, N. Barquero, D. Bautista, J. Gil-Rubio and J. Vicente, Chem. - Eur. J., 2015, 21, 1992-2002.

54 V. Camara, N. Barquero, D. Bautista, J. Gil-Rubio and J. Vicente, Inorg. Chem., 2015, 54, 6147-6156.

55 V. W. W. Yam, S. W. K. Choi and K. K. Cheung, Organometallics, 1996, 15, 1734-1739.
56 V. W. W. Yam and S. W. K. Choi, J. Chem. Soc., Dalton Trans., 1996, 4227-4232.

57 I. O. Koshevoy, L. Koskinen, E. S. Smirnova, M. Haukka, T. A. Pakkanen, A. S. Melnikov and S. P. Tunik, Z. Anorg. Allg. Chem., 2010, 636, 795-802.

58 X. M. He, E. C. C. Cheng, N. Y. Zhu and V. W. W. Yam, Chem. Commun., 2009, 4016-4018.

59 T. M. Dau, J. R. Shakirova, A. Domenech, J. Janis, M. Haukka, E. V. Grachova, T. A. Pakkanen, S. P. Tunik and I. O. Koshevoy, Eur. J. Inorg. Chem., 2013, 49764983.

60 S. L. James, Chem. Soc. Rev., 2009, 38, 1744-1758.

61 P. Rosa, A. Debay, L. Capes, G. Chastanet, A. Bousseksou, P. Le Floch and J.-F. Létard, Eur. J. Inorg. Chem., 2004, 3017-3019.

62 P. W. Miller, M. Nieuwenhuyzen, J. P. H. Charmant and S. L. James, Inorg. Chem., 2008, 47, 8367-8379.

63 J. Vicente and M. T. Chicote, Coord. Chem. Rev., 1999, 195, 1143-1161.

64 J. Vicente, M. T. Chicote, M. M. Alvarez-Falcon and P. G. Jones, Organometallics, 2005, 24, 5956-5963.

65 L. Rodriguez, C. Lodeiro, J. C. Lima and R. Crehuet, Inorg. Chem., 2008, 47, 4952-4962.

66 J. Vicente, M. Chicote, R. Guerrero, P. Jones and M. de Arellano, Inorg. Chem., 1997, 36, 4438-4443.

67 E. Fernandez, M. Gimeno, P. Jones, A. Laguna, J. Lopezde-Luzuriaga and E. Olmos, Chem. Ber./Recl., 1997, 130, 1513-1517.

68 E. J. Fernandez, M. C. Gimeno, P. G. Jones, A. Laguna, M. Laguna and E. Olmos, J. Chem. Soc., Dalton Trans., 1996, 3603-3608.

69 M. Ferrer, A. Gutierrez, M. Mounir, L. Rodriguez, O. Rossell, M. Font-Bardia, P. Gomez-Sal, A. Martin and X. Solans, Organometallics, 2011, 30, 3419-3429.

$70 \mathrm{H}$. Schmidbaur, A. Stutzer and P. Bissinger, $Z$. Naturforsch., B: Chem. Sci., 1992, 47, 640-644.

71 P. Bonakdarzadeh, F. Pan, E. Kalenius, O. Jurček and K. Rissanen, Angew. Chem., Int. Ed., 2015, 54, 1489014893.

72 J. Ni, X. Zhang, Y.-H. Wu, L.-Y. Zhang and Z.-N. Chen, Chem. - Eur. J., 2011, 17, 1171-1183.

73 F. Paul, S. Goeb, F. Justaud, G. Argouarch, L. Toupet, R. F. Ziessel and C. Lapinte, Inorg. Chem., 2007, 46, 90369038.

74 G. A. Koutsantonis, P. J. Low, C. F. R. Mackenzie, B. W. Skelton and D. S. Yufit, Organometallics, 2014, 33, 4911-4922.

75 L. Rodríguez, M. Ferrer, R. Crehuet, J. Anglada and J. C. Lima, Inorg. Chem., 2012, 51, 7636-7641.

76 R. Gavara, E. Aguiló, C. Fonseca Guerra, L. Rodríguez and J. C. Lima, Inorg. Chem., 2015, 54, 5195-5203.

77 E. Aguilo, R. Gavara, C. Baucells, M. Guitart, J. C. Lima, J. Llorca and L. Rodriguez, Dalton Trans., 2016, 45, 73287339.

78 R. Gavara, J. C. Lima and L. Rodriguez, Photochem. Photobiol. Sci., 2016, 15, 635-643. 
79 K. Nakamoto, J. Phys. Chem., 1960, 64, 1420-1425.

80 S. Comby, D. Imbert, A.-S. Chauvin, J.-C. G. Bünzli, L. J. Charbonnière and R. F. Ziessel, Inorg. Chem., 2004, 43, 7369-7379.

81 L. J. Charbonnière, N. Weibel, P. Retailleau and R. Ziessel, Chem. - Eur. J., 2007, 13, 346-358.

82 R. A. Binstead, B. Jung and A. D. Zuberbühler, SPECFIT/32 Global Analysis System, 3.0, Spectrum Software Associates, USA, 2000.

83 X. Jiang, B. Gyu Park, J. A. Riddle, B. June Zhang, M. Pink and D. Lee, Chem. Commun., 2008, 6028-6030.

84 Z. Xu, J. Yoon and D. R. Spring, Chem. Soc. Rev., 2010, 39, 1996-2006.

85 R. Usón and A. Laguna, Organomet. Synth., 1986, 3, 322342.

86 J. Vicente and M. T. Chicote, Inorg. Synth., 1998, 32, 173174.

87 V. Grosshenny, F. M. Romero and R. Ziessel, J. Org. Chem., 1997, 62, 1491-1500.

88 S. A. Li, C. N. Moorefield, C. D. Shreiner, P. S. Wang, R. Sarkar and G. R. Newkome, New J. Chem., 2011, 35, 2130-2135.

89 J. Fawcett, P. A. T. Hoye, R. D. W. Kemmitt, D. J. Law and D. R. Russell, J. Chem. Soc., Dalton Trans., 1993, 25632568 .
90 T. Yi, M. Mo, H. Y. Fu, R. X. Li, H. Chen and X. J. Li, Catal. Lett., 2012, 142, 594-600.

91 A. F. Chiffey, J. Evans and W. Levason, Polyhedron, 1996, 15, 1309-1314.

92 P. M. VanCalcar, M. M. Olmstead and A. L. Balch, Chem. Commun., 1996, 2597-2598.

93 E. J. Fernandez, A. Laguna, J. M. Lopez-de-Luzuriaga, M. Monge, M. Montiel, M. E. Olmos, R. C. Puelles and E. Sanchez-Forcada, Eur. J. Inorg. Chem., 2007, 4001-4005.

94 CrysAlisPro 2015, Version 1.171.38.43, Rigaku Oxford Diffraction.

95 G. M. Sheldrick, Acta Crystallogr., Sect. A: Fundam. Crystallogr., 2008, 64, 112-122.

96 G. M. Sheldrick, Acta Crystallogr., Sect. A: Fundam. Crystallogr., 2015, 71, 3-8.

97 O. V. Dolomanov, L. J. Bourhis, R. J. Gildea, J. A. K. Howard and H. Puschmann, J. Appl. Crystallogr., 2009, 42, 339-341.

98 L. J. Farrugia, J. Appl. Crystallogr., 2012, 45, 849-854.

99 G. M. Sheldrick, Acta Crystallogr., Sect. C: Cryst. Struct. Commun., 2015, 71, 3-8.

100 A. L. Spek, Acta Crystallogr., Sect. C: Cryst. Struct. Commun., 2015, 71, 9-18.

101 H. Christina, E. McFarlane and W. McFarlane, Polyhedron, 1988, 7, 1875-1879. 